\title{
A Truncated Tropo-Myosine-Related Kinase B Receptor, T1, Regulates Glial Cell Morphology via Rho GDP Dissociation Inhibitor 1
}

\author{
Koji Ohira, ${ }^{1,2}$ Haruko Kumanogoh, ${ }^{1}$ Yoshinori Sahara, ${ }^{1}$ Koichi J. Homma, ${ }^{3}$ Hirohisa Hirai, ${ }^{2}$ Shun Nakamura, ${ }^{1}$ and \\ Motoharu Hayashi ${ }^{2}$ \\ ${ }^{1}$ Department of Biochemistry and Cellular Biology, National Institute of Neuroscience, National Center of Neurology and Psychiatry, Tokyo 187-8502, \\ Japan, ${ }^{2}$ Department of Cellular and Molecular Biology, Primate Research Institute, Kyoto University, Inuyama, Aichi 484-8506, Japan, and ${ }^{3}$ Department of \\ Molecular Pathology, Faculty of Pharmaceutical Sciences, Teikyo University, Kanagawa 199-0195, Japan
}

Through tropo-myosine-related kinase B (TrkB) receptors, brain-derived neurotrophic factor (BDNF) performs many biological functions such as neural survival, differentiation, and plasticity. T1, an isoform of TrkB receptors that lacks a tyrosine kinase, predominates in the adult mammalian CNS, yet its role remains controversial. In this study, to examine whether $\mathrm{T} 1$ transduces a signal and to determine its function, we first performed an affinity purification of T1-binding protein with the T1-specific C-terminal peptide and identified Rho GDP dissociation inhibitor 1 (GDI1), a GDP dissociation inhibitor of Rho small G-proteins, as a signaling protein directly associated with T1. The binding of BDNF to T1 caused Rho GDI1 to dissociate from the C-terminal tail of T1. Astrocytes cultured for $30 \mathrm{~d}$ expressed only endogenous T1 among the BDNF receptors. In $30 \mathrm{~d}$ cultured astrocytes, Rho GDI1, when dissociated in a BDNF-dependent manner, controlled the activities of the Rho GTPases, which resulted in rapid changes in astrocytic morphology. Furthermore, using $2 \mathrm{~d}$ cultured astrocytes that were transfected with T1, a T1 deletion mutant, or cyan fluorescent protein fusion protein of the T1-specific C-terminal sequence, we demonstrated that T1-Rho GDI1 signaling was indispensable for regulating the activities of Rho GTPases and for the subsequent morphological changes among astrocytes. Therefore, these findings indicate that the T1 signaling cascade can alter astrocytic morphology via regulation of Rho GTPase activity.

Key words: astrocyte; BDNF; primary culture; Rho GDI; Rho GTPase; truncated TrkB; T1

\section{Introduction}

Brain-derived neurotrophic factor (BDNF) is enriched in the CNS and plays pivotal roles in neural survival, differentiation, and plasticity (Bibel and Barde, 2000; Thoenen, 2000). The effects of BDNF are transduced through the tropo-myosine-related kinase B (TrkB) receptor (Barbacid, 1994). There are three TrkB receptor isoforms in the mammalian CNS (Barbacid, 1994). The full-length isoform $(\mathrm{TK}+)$ is a typical tyrosine kinase receptor and transduces the BDNF signal (Kaplan and Miller, 2000). In contrast, two truncated isoforms (TK-: T1 and T2) possess the same extracellular domain, transmembrane domain, and first 12 intracellular amino acid sequences as $\mathrm{TK}+$. However, the

Received May 26, 2004; revised Dec. 20, 2004; accepted Dec. 22, 2004.

This work was supported by Grants-in-Aid for Scientific Research on Priority Areas and the Advanced Brain Science Project (15016056 and 16015341 to M.H. and S.N.); by a Grant-in Aid for the Biodiversity Research of 21st Century Center of Excellence (A14) from the Ministry of Education, Culture, Sports, Science and Technology of Japan; and by Health Sciences Research grants from the Organization of Pharmaceutical Safety and Research and Research on Advanced Medical Technology (nano-1 and MF-3). We thank Dr. Hans Thoenen for his critical reading of this manuscript; Drs. Yoshihiro Sokawa, Shohei Maekawa, Takayoshi Inoue, and Nobuo Funatsu for their helpful comments; and Tomomi Ochiai-Ohira for her photographic expertise.

Correspondence should be addressed to Dr. Motoharu Hayashi, Department of Cellular and Molecular Biology, Primate Research Institute, Kyoto University, Kanrin, Inuyama, Aichi 484-8506, Japan. E-mail: hayashi@pri.kyoto-u.ac.jp.

DOI:10.1523/JNEUROSCI.4436-04.2005

Copyright $\odot 2005$ Society for Neuroscience $\quad$ 0270-6474/05/251343-11\$15.00/0
C-terminal sequences are the isoform specific (11 and 9 amino acids, respectively) (Barbacid, 1994).

Currently, TK-, especially $\mathrm{T} 1$, is hypothesized to be a dominant-negative form of $\mathrm{TK}+$ and is involved in negative functions against $\mathrm{TK}+$, such as the $\mathrm{TK}+$ phosphorylation (Knüsel et al., 1994), the calcium efflux (Eide et al., 1996), the cell survival activity (Haapasalo et al., 2001), and gene expression by BDNF (Offenhäuser et al., 2002). According to this hypothesis, $\mathrm{TK}-$ is postulated to form the homodimer or heterodimer with $\mathrm{TK}+$, which prohibits $\mathrm{TK}+$ signaling or limits the availability of BDNF to the neural tissue by trapping excess BDNF.

In contrast, there are several findings that provide evidence against the hypothesis that $\mathrm{T} 1$ is a dominant-negative form of $\mathrm{TK}+$. For example, the expression of $\mathrm{T} 1$ increases markedly at various important periods in the developing mammalian CNS, such as axonal remodeling and synaptogenesis (Allendoerfer et al., 1994; Fryer et al., 1996; Ohira et al., 1999, 2001). The specific alignment of the intracellular domain of T1 is completely identical among mice, rats, and humans (Klein et al., 1990; Middlemas et al., 1991; Shelton et al., 1995), suggesting that the alignment plays a unique role. In addition, $\mathrm{T} 1$ is capable of binding BDNF at the same level as does TK+ (Biffo et al., 1995). As regards the physiological function of T1, it is involved in the control of the elongation of distal dendrites of cortical pyramidal neurons (Ya- 
coubian and Lo, 2000) and the BDNF-induced calcium entry in astrocytes (Rose et al., 2003). Based on these results, we considered a new hypothesis, namely, that T1 binds to proteins through its C-terminal-specific sequence, which elicits a unique type of signal transduction other than the well understood regulation of the tyrosine kinase pathway. In fact, $\mathrm{T} 1$ has been reported to mediate signal transduction (i.e., the acid metabolite release from cells) (Baxter et al., 1997).

To clarify the T1 signaling cascade, in this study, we first performed affinity purification with a T1-specific sequence and then identified Rho GDP dissociation inhibitor 1 (GDI1) as a T1 binding protein from the rat brain. Rho GDI1 is an inhibitory regulator of Rho GTPases that can regulate cell morphology via the remodeling of the cytoskeleton. Furthermore, we provide evidence that $\mathrm{T} 1$ is capable of ligand-mediated signaling through Rho GDI1 and of regulating astrocytic morphology in primary cultures.

\section{Materials and Methods}

Affinity chromatography. All experimental procedures for animals were performed in accordance with our institutional guidelines (1996). Young adult (4-week-old) Wistar rat whole brains $(10 \mathrm{~g})$ were homogenized in $10 \mathrm{vol}$ of homogenization buffer $(0.32 \mathrm{M}$ sucrose, $5 \mathrm{~mm}$ Tris- $\mathrm{HCl}, \mathrm{pH} 7.5$, and $150 \mathrm{~mm} \mathrm{NaCl}$ containing $1 \mathrm{~mm}$ PMSF, $10 \mu \mathrm{g} / \mathrm{ml}$ leupeptine, and 20 $\mu \mathrm{g} / \mathrm{ml}$ aprotinin). After centrifugation at $100,000 \times g$ at $4^{\circ} \mathrm{C}$ for $1 \mathrm{~h}$, the supernatant was adjusted to a concentration of $1 \mathrm{mg} / \mathrm{ml}$ protein, and this solution was defined as the cytosolic fraction. Eleven synthesized amino acid residues (FVLFHKIPLDG) of the $C$ terminal of T1 were conjugated to a poly- $\beta$-hydroxybutyrate-Tenta Gel S (Shimadzu, Kyoto, Japan) matrix. The affinity column was equilibrated with the homogenization buffer. Another column, without the synthetic peptides, was prepared as a control column. Ten milliliter aliquots of the cytosolic fraction were applied to the control column and then were loaded onto the affinity column. After the affinity column was washed with homogenization buffer containing $500 \mathrm{~mm} \mathrm{NaCl}$, the bound proteins were eluted in one step with $50 \mathrm{~mm}$ glycine, $\mathrm{pH} 2.5$. Ten microliters of each fraction $(200 \mu \mathrm{l})$ were subjected to SDS-PAGE ( $10 \%$ gel). The proteins in the gels were then silver stained.

Amino acid sequence analysis. The fractions containing the $28 \mathrm{kDa}$ protein, which had been obtained from 20 independent affinity chromatography experiments, were concentrated using Centricon YM-10 (Millipore, Bedford, MA). The proteins were transferred to a polyvinylidene difluoride (PVDF) membrane (Millipore) using a buffer containing 10 mм 3-[(3-cholamidopropyl)dimethylammonio]-1-propanesulfonate and $10 \%$ methanol, $\mathrm{pH} 11$. The membranes were stained with $0.1 \%$ Ponceau $\mathrm{S}$ in $1 \%$ acetic acid and were destained with distilled water. For the peptide sequence, immobilized protein bands were cut with $2 \mathrm{mg}$ of $\mathrm{CNBr}$ and placed in $200 \mu \mathrm{l}$ of $70 \%$ formic acid in an Eppendorf (Eppendorf Scientific, Westbury, NY) tube overnight. The resulting solution and membranes were dried and then boiled in SDS sample buffer. Tricine-SDS-PAGE was used to segregate the small peptides ( $<10 \mathrm{kDa}$ ) (Ploug et al., 1989). The cut peptides were transferred to $\mathrm{PVDF}^{\mathrm{SQ}}$ membranes (Millipore), which were then stained with $0.1 \%$ Ponceau $S$ in $1 \%$ acetic acid and destained with distilled water. The bands were applied to a Sequencer (476A protein sequencer; Applied Biosystems, Foster City, CA).

Cell cultures. For the cell cultures, human embryonic kidney 293 (HEK293) cells were kept in DMEM supplemented with 10\% FBS. Astrocytic primary cultures were prepared from neonatal rat pups (Sprague Dawley). The hippocampi were cut into $1 \mathrm{~mm}$ slices, incubated in activated papain $(20 \mathrm{U} / \mathrm{ml}, 20 \mathrm{~min})$, and dissociated by gentle trituration (Sahara and Westbrook, 1993). Dissociated astrocytes from neonatal rats were plated at 300,000 cells per dish on cover glasses coated with poly-Llysine (Sigma, St. Louis, MO). The culture medium contained MEM (Invitrogen, Carlsbad, CA), 0.6\% glucose, 5\% heat-inactivated FBS, and penicillin-streptomycin (Invitrogen). At $3 \mathrm{~d}$ in vitro (DIV) after plating, the expression plasmid vectors (see below) were transfected into astrocytes with Lipofectamine 2000 (Invitrogen). At $4 \mathrm{~h}$ after transfection, the culture media were exchanged to DMEM containing N2 supplement (Invitrogen). After $24 \mathrm{~h}$, the cells were used for the experiments. For the long-term cultured astrocytes, cells were incubated in DMEM with 5\% FBS, and the medium was exchanged every $3 \mathrm{~d}$. At $72 \mathrm{~h}$ before the experiments, the culture media were replaced with DMEM containing the N2 supplement. Additionally, the media of all cultures were exchanged for fresh media at $2 \mathrm{~h}$ before the experiments.

Reverse-transcription PCR. Total RNA was isolated from primary astrocytes with Isogen (Nippon Gene, Tokyo, Japan). Total RNA ( $2 \mu \mathrm{g})$ was reverse transcribed into cDNA in $20 \mu \mathrm{l}$ of $1 \times$ first-strand buffer containing $0.5 \mu \mathrm{g}$ of oligo-dT as a primer, $500 \mu \mathrm{M} \mathrm{dNTP}$, and $200 \mathrm{U}$ of SuperScript II (Invitrogen). PCR was performed in $20 \mu \mathrm{l}$ of $1 \times$ PCR buffer containing $2 \mu \mathrm{l}$ of reverse transcription (RT) products, $1 \mathrm{U}$ of AmpliTaq DNA polymerase (Roche Applied Science, Basel, Switzerland), $200 \mu \mathrm{M}$ dNTP, and $0.4 \mu \mathrm{M}$ of the primer pair. We used the endogenous internal standard ( $\beta$-actin, 5'-TAAAACGCAGCTCAGTAACAGTCCG- ${ }^{\prime}$ and $5^{\prime}$-TGGAATCCTGTGGCATCCATGAAAC- ${ }^{\prime}$; 348 bp) and specific primers for TK+ (5'-ATAACGGAGACTACACCCTGATGG-3' and 5'-AGCTGACTGTTGGTGATGCC-3'; 505 bp), T1 (5'-CATAAGATCCCACTGGATGGGTAG-3' and 5' -GCTGCAGACATCCTCGGAGATTAC-3'; 177 bp), T2 (5'-CAGAAGTGTGCTTATTTTGC-3' and 5' -AGACAATACAGGTCTACCTCTCAG-3'; 553 bp), or p75 (5' ${ }^{\prime}$-TGTGTGAAGAGTGCCCAGAG-3' and $5^{\prime}$-TCACCATATCCGCCACTGTA-3'; $263 \mathrm{bp}$ ). The PCR parameters were $94^{\circ} \mathrm{C}$ for $30 \mathrm{~s}, 58^{\circ} \mathrm{C}$ for $30 \mathrm{~s}$, and $72^{\circ} \mathrm{C}$ for $60 \mathrm{~s}$ for 30 cycles, followed by a final elongation at $72^{\circ} \mathrm{C}$ for $5 \mathrm{~min}$. The amplified PCR products were separated on $1.5 \%$ agarose gel.

DNA constructs and transfection. The T1 cDNA obtained from the adult rat cortex was subcloned into the EcoRI sites of p internal ribosomal entry site (IRES) 2-enhanced green fluorescent protein (EGFP) (Clontech, Palo Alto, CA), and the resulting construct was designated as pT1IRES-EGFP. Mutant constructs of T1 were prepared by a PCR mutagenesis method. Briefly, we used the $5^{\prime}$ primer for T1, GGTCTGCCGTCTGCACGTCTG, and the $3^{\prime}$ primers A, CGCGGATCCCTAGAGCAGAAGCAGCATC; B, CGCGGATCCTTAACCTTTCATGCC; C, CGCGGATCCCTAAACAAAACCTTTC; D, CGCGGATCCCTAATGAAACAAAACAAAAC; and E, CGCGGATCCCTAGGGGATCTTATG. The underlined sequences indicate the BamH1 sites. The boldface letters represent mutation sites. PCR was performed at $94^{\circ} \mathrm{C}$ for $30 \mathrm{~s}$, $58^{\circ} \mathrm{C}$ for $30 \mathrm{~s}$, and $72^{\circ} \mathrm{C}$ for $60 \mathrm{~s}$ for $30 \mathrm{cycles}$, followed by a final elongation at $72^{\circ} \mathrm{C}$ for 5 min with an Expand High Fidelity PCR system (Roche Applied Science). The amplified PCR products were separated on 2\% agarose gel. The PCR products were digested at the 5' BstPI and the $3^{\prime}$ $B a m \mathrm{H} 1$ sites, and the digested products were subcloned into pT1-IRESEGFP. The vectors of enhanced cyan fluorescent protein (ECFP)- $\Delta 11$ and ECFP-intracellular domain (ICD) were also prepared by PCR, using the $5^{\prime}$ primer GGTCTGCCGTCTGCACGTCTG and the $3^{\prime}$ primer of $\Delta 11$, CGCGGATCCTTAACCTTTCATGCC or the $3^{\prime}$ primer of ICD, CGCGGATCCCCCAGCCTTGTCTTTCCTTTATC. The deletion mutants are shown in Figure 3. The underlined sequences indicate the $\mathrm{Bam} \mathrm{H} 1$ sites, and the boldface letters represent mutation sites. PCR was performed at $94^{\circ} \mathrm{C}$ for $30 \mathrm{~s}, 58^{\circ} \mathrm{C}$ for $30 \mathrm{~s}$, and $72^{\circ} \mathrm{C}$ for $60 \mathrm{~s}$ for $30 \mathrm{cycles}$, followed by a final elongation at $72^{\circ} \mathrm{C}$ for 5 min with an Expand High Fidelity PCR system (Roche Applied Science). The amplified PCR products were separated on $2 \%$ agarose gel. The PCR products were digested by the $5^{\prime}$ and $3^{\prime}$ BamH1 sites and were then subcloned into these sites of pECFP-C1 (Clontech). These constructs were transfected into HEK293 cells and astrocytes with Lipofectamine 2000.

Production of glutathione S-transferase-fusion proteins and in vitro binding assay. Constructs of glutathione $S$-transferase (GST)-fusion proteins were prepared by a PCR method. For the preparation of GST-T1ICD, we used the above pT1-IRES-EGFP as a template, the $5^{\prime}$ primer CAAGAATTCCTCCAAGTTGGCGAGACATTCC, and the $3^{\prime}$ primer GTTGTCGACTTGTCTTTCCTTTATCTCAG. The single-underlined sequence indicates the EcoRI site, and the double-underlined sequence indicates the SalI site. PCR was performed at $94^{\circ} \mathrm{C}$ for $30 \mathrm{~s}, 58^{\circ} \mathrm{C}$ for $30 \mathrm{~s}$, and $72^{\circ} \mathrm{C}$ for $60 \mathrm{~s}$ for 25 cycles, followed by a final elongation at $72^{\circ} \mathrm{C}$ for 5 min with an Expand High Fidelity PCR system. The digested PCR product was subcloned into the pGEX-5X-3 bacterial expression vector 
A

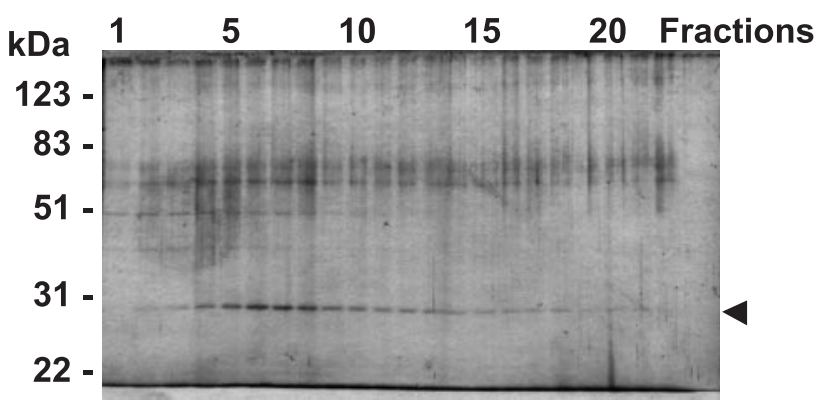

Figure 1. Affinity purification of a binding protein of T1. $A$, The cytosolic fraction from rat brain was loaded onto an affinity column with the $\mathrm{T} 1$ synthetic peptide. One-step elution with glycine $(50 \mathrm{~mm} ; \mathrm{pH} 2.5)$ was performed, and elution samples from the column were separated; an aliquot of each eluate was subjected to SDS-PAGE ( $10 \%$ gel). The resulting silver-stained gel image is shown here. The arrowhead indicates the position of the $28 \mathrm{kDa}$ protein. $B$, Western blot analysis of the eluate from the control column (lane 1) and the affinity column (lane 2) with anti-Rho GDI1. The arrowhead indicates the position of Rho GDI1 (28 kDa).

A

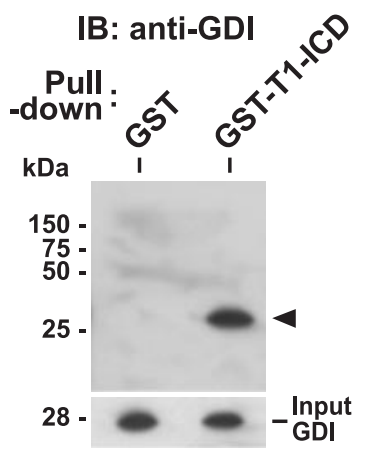

B
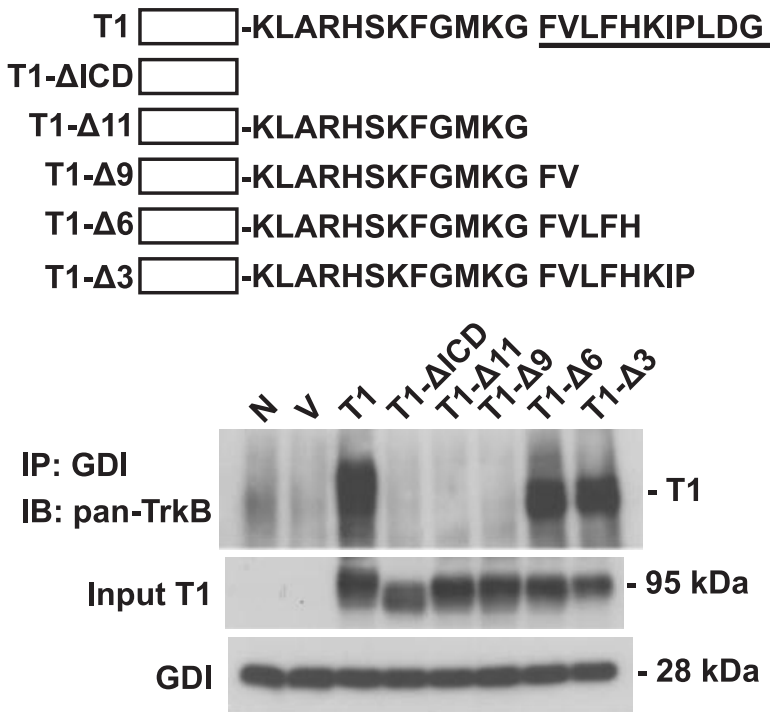

Figure 2. Direct binding of Rho GDI1 to T1 and binding motif in the T1-specific sequence. $A$, The GST moiety or the GST-T1-ICD was mixed with recombinant Rho GDI1 in Eppendorf tubes. The GST proteins were precipitated with glutathione-Sepharose 4B. The coprecipitated Rho GDI1 was detected with anti-Rho GDI1. The arrowhead indicates Rho GDI1 (28 kDa). $B$, The Rho GDI1 binding site in the intracellular domain of T1. A display of T1 and its deletion mutants is shown in the top panel. The white boxes represent the extracellular and transmembrane domains, and the underlined sequence indicates the specific amino acid sequence of T1. The constructs were transfected into HEK293 cells. After $24 \mathrm{~h}$, coimmunoprecipitation with anti-Rho GDI1 was performed. $\mathrm{N}$, No vector; $V$, empty vector expressing GFP; $T 1$, normal $\mathrm{T} 1 ; \mathrm{T} 1-\Delta \mathrm{ICD}, \mathrm{T} 1$ without its ICD; $\mathrm{T} 1-\Delta \mathrm{n}$, $\mathrm{T} 1$ deletion mutants lacking the indicated number of amino acids from the C terminal. IB, Immunoblot; IP, immunoprecipitation.

(Amersham Biosciences, Piscataway, NJ). To obtain the cDNA of Rho GDI1, we used a cDNA library of the adult mouse cortex as a template, the $5^{\prime}$ primer CACGAATTCTAGGGCAGAACAGGACC, and the $3^{\prime}$ primer GTTGTCGACTAGGTAGGGGGTTAG. A single-underlined sequence indicates the $E c o$ RI site, and a double-underlined sequence indicates the SalI site. The boldface letter in the $5^{\prime}$ primer of GST-Rho GDI1 is the point mutation site. The methods used for PCR preparation and subcloning into the pGEX-5X-3 vector were the same as those used for T1. After the $\mathrm{OD}_{600}$ reached $0.6,1 \mathrm{~mm}$ isopropyl-1-thio- $\beta$-Dgalactopyranoside was added to the cultures, and Escherichia coli were grown for an additional $16 \mathrm{~h}$ at $25^{\circ} \mathrm{C}$ (Yamashita and Tohyama, 2003). After the cells were collected, they were resuspended in PBS and sonicated. To the cell lysates, $0.5 \%$ Triton X-100 was added, and the samples were incubated for $30 \mathrm{~min}$ at $4^{\circ} \mathrm{C}$. After centrifugation at $10,000 \times \mathrm{g}$ for 5 min, glutathione-Sepharose $4 \mathrm{~B}$ (Pharmacia, Piscataway, NJ) was added to the supernatants, which were then incubated for $30 \mathrm{~min}$ at $4^{\circ} \mathrm{C}$. After centrifugation at $10,000 \times g$ for $5 \mathrm{~s}$, the beads were washed three times in PBS containing $0.5 \%$ Triton X-100. The purity of the proteins was determined by SDS-PAGE. Then, glutathione-Sepharose 4B with GST-T1-ICD was used for the binding assay. To remove the GST moiety from GST-Rho GDI1, Factor Xa (Novagen, Darmstadt, Germany) was added to the glutathione-Sepharose 4B with GST-Rho GDI1, and the samples were incubated for $16 \mathrm{~h}$ at $20^{\circ} \mathrm{C}$. After centrifugation at $10,000 \times g$ for 5 min, Xarrest agarose (Novagen) was added to the supernatants, and the samples were incubated for $10 \mathrm{~min}$ at room temperature. After centrifugation at $1000 \times g$ for $5 \mathrm{~min}$, the supernatants were designated as the recombinant Rho GDI1 without GST. To check the cleavage of GST-Rho GDI1, glutathione-Sepharose 4B was added into the supernatant of Rho GDI1, and the samples were incubated for $30 \mathrm{~min}$ at $4^{\circ} \mathrm{C}$. After centrifugation at $10,000 \times g$ for 5 $\mathrm{min}$, the precipitates were washed three times in PBS containing $0.5 \%$ Triton X-100, and they were then boiled in SDS sample buffer (see supplemental Fig. 1, available at www.jneurosci.org as supplemental material).

For the in vitro binding assay, recombinant Rho GDI1 solution was added to the glutathione-Sepharose 4B with GST-T1-ICD, and the samples were incubated for $1 \mathrm{~h}$ at $4^{\circ} \mathrm{C}$ with agitation. After centrifugation at $10,000 \times$ $g$ for $5 \mathrm{~s}$, the precipitates were washed three times in PBS containing $0.5 \%$ Triton X-100, and then they were boiled in SDS sample buffer.

Precipitation assays. After each incubation with reagents, the cells were lysed with $0.15 \mathrm{ml}$ of lysis buffer. For Rho GDI1-T1 coimmunoprecipitation, lysis buffer A (10 mM triethanolamine, 10 mm iodoacetoamine, $\mathrm{pH} 7.8,150 \mathrm{~mm}$ $\mathrm{NaCl}, 2$ mм EDTA, 1\% digitonin, 1 mm PMSF, $10 \mu \mathrm{g} / \mathrm{ml}$ leupeptin, and $20 \mu \mathrm{g} / \mathrm{ml}$ aprotinin) was used. The lysates were centrifuged at $10,000 \times g$ at $4^{\circ} \mathrm{C}$ for $20 \mathrm{~min}$. Then, $50 \mu$ laliquots of resulting supernatants were designated as total protein samples. Normal mouse IgG and protein G-Sepharose were added to the remaining supernatants, which were incubated at $4^{\circ} \mathrm{C}$ for $1 \mathrm{~h}$ with gentle rotation. After centrifugation at $5000 \times g$ at $4^{\circ} \mathrm{C}$ for $1 \mathrm{~min}$, mouse monoclonal anti-pan-TrkB ( $2 \mu \mathrm{l}$; Transduction Laboratories, Lexington, KY) or rabbit polyclonal anti-Rho GDI1 (3 $\mu$ l; Santa Cruz Biotechnology, Santa Cruz, CA) was added. In the competitive assays with the synthetic peptides of the T1 C terminal, the peptides (final concentration, $100 \mu \mathrm{m}$ and $1 \mathrm{~mm}$ ) were added to the lysates and incubated at $4^{\circ} \mathrm{C}$ for $1 \mathrm{~h}$. The samples were incubated at $4^{\circ} \mathrm{C}$ for $2 \mathrm{~h}$ with antibody and then were incubated with protein G-Sepharose at $4^{\circ} \mathrm{C}$ for $1 \mathrm{~h}$ with gentle rotation. The precipitates were washed four times with lysis buffer $\mathrm{A}$ and boiled in 40 $\mu l$ of SDS sample buffer for 3 min.

For the RhoA, Rac1, and Cdc42 pull-down assay, we used lysis buffer B [50 mм Tris- $\mathrm{HCl}, \mathrm{pH} 7.5,150 \mathrm{~mm} \mathrm{NaCl}, 5 \mathrm{~mm} \mathrm{MgCl}_{2}, 0.5 \%$ Triton $\mathrm{X}-100,1 \mathrm{~mm}$ PMSF, $10 \mu \mathrm{g} / \mathrm{ml}$ leupeptin, $20 \mu \mathrm{g} / \mathrm{ml}$ aprotinin, and $10 \mathrm{~nm}$ microcystin LR (Leu and Avg)]. The lysates were centrifuged at 10,000 $\times$ $g$ at $4^{\circ} \mathrm{C}$ for $20 \mathrm{~min}$. We then performed the RhoA pull-down assay with Rhotekin beads (Upstate Biotech, Charlottesville, VA) according to the method of Ren et al. (1999) and the Rac1 and Cdc42 pull-down assay with p21-activated kinase (PAK) beads (Upstate Biotech). Then, the Rhotekin (Upstate Biotech) or PAK beads $(30 \mu \mathrm{l})$ were added to the lysates $\left(1 \mathrm{mg}\right.$ of protein $/ \mathrm{ml}$ ) and incubated at $4^{\circ} \mathrm{C}$ for $45 \mathrm{~min}$. The beads 
were washed three times with lysis buffer B. The pellets were then mixed with $40 \mu \mathrm{l}$ of SDS sample buffer and boiled for $3 \mathrm{~min}$. In the control assays using GTP $\gamma \mathrm{S}$ - and GDP-loaded lysates, we confirmed our assay systems (supplemental Fig. 2, available at www.jneurosci.org as supplemental material). Briefly, $3 \mu \mathrm{l}$ of $0.5 \mathrm{M}$ EDTA $(10 \mathrm{mM})$ and then $1.5 \mu \mathrm{l}$ of GTP $\gamma \mathrm{S}(100 \mu \mathrm{M})$ or GDP ( $1 \mathrm{~mm}$ ) was added to a $0.15 \mathrm{ml}$ aliquot of each cell extract. The extracts were incubated at $30^{\circ} \mathrm{C}$ for $30 \mathrm{~min}$. To stop the loading of GTP $\gamma \mathrm{S}$ and GDP, we added $9 \mu \mathrm{l}$ of $1 \mathrm{M} \mathrm{MgCl}_{2}(60 \mathrm{~mm})$. The procedures that were subsequently performed have been described above.

Western blot analysis. Using an aliquot of astrocytic culture lysates, we also performed a Western blot analysis of protein expression. The samples ( $5 \mu \mathrm{g}$ total protein per lane, except for TrkB, Cdc42, and Rac1, as follows: $100 \mu \mathrm{g}$ total protein per lane for TrkB, Cdc42, and Rac1 and $10 \mu \mathrm{l}$ per lane for the precipitates) were subjected to SDS-PAGE and then were blotted onto PVDF membranes. The membranes were blocked for $1 \mathrm{~h}$ in 5\% skim milk in PBS [containing (in $\mathrm{mm}$ ): $137 \mathrm{NaCl}, \quad 8.1$ $\mathrm{Na}_{2} \mathrm{HPO}_{4} \cdot 7 \mathrm{H}_{2} \mathrm{O}, 2.7 \mathrm{KCl}$, and $\left.1.5 \mathrm{KH}_{2} \mathrm{PO}_{4}\right]$. After incubation with the primary antibodies at room temperature for $1 \mathrm{~h}$, the blots were incubated for $1 \mathrm{~h}$ with secondary antibodies conjugated with HRP and then were visualized by the ECL system (Amersham Biosciences). For the primary antibodies, we used anti-pan-TrkB (1: 200; Santa Cruz Biotechnology), anti-TK+ (1: 200; Santa Cruz Biotechnology), anti-T1 (1:200; Santa Cruz Biotechnology), anti-RhoA (1:200; Santa Cruz Biotechnology), anti-Rac1 (1:1000; Transduction Laboratories), antiCdc42 (1:1000; Transduction Laboratories), anti-Rho GDI1 (1:200; Santa Cruz Biotechnology), and anti- $\beta$-tubulin (1:1000; Sigma).

Immunohistochemistry. Young adult rats (4-week-old Wistar rats) were anesthetized and perfused with $4 \%$ formaldehyde in phosphate buffer. The brains were postfixed for $6 \mathrm{~h}$ and cryoprotected in $30 \%$ sucrose in PBS. The brains were mounted in Tissue-Tek (Miles, Elkhart, IN), frozen rapidly on dry ice, and stored at $-30^{\circ} \mathrm{C}$. The sections were cut to a thickness of $35 \mu \mathrm{m}$ with a cryostat (Leica, Wetzlar, Germany). The sections were mounted on glass slides coated with 3-aminopropyltriethoxysilane, washed for 30 min with PBS, and then preincubated with PBS-GB [4\% normal goat serum (Vector Laboratories, Burlingame, CA) and 1\% bovine serum albu$\mathrm{min}$ in $\mathrm{PBS}$ ] for $2 \mathrm{~h}$ at room temperature. The sections were incubated for $48 \mathrm{~h}$ at $4^{\circ} \mathrm{C}$ with antibodies. We used the following primary antibodies: rabbit polyclonal anti-TK+ $(1: 800)$ and anti-T1 $(1: 800)$ and mouse monoclonal anti-neurofilament (1:1000; clone SMI32; Sternberger Monoclonals, Lutherville, MD), anti-glutamic acid decarboxylase (GAD; 1:3000; Affinity Research Products, Exeter, UK), and anti-glial fibrillary acidic protein (GFAP; 1:1000; Chemicon, Temecula, CA). The sections were incubated for $1 \mathrm{~h}$ at room temperature with the following secondary antibodies: anti-mouse IgG cyanine 3 (Cy3; 1:200; Chemicon) and anti-rabbit IgG Alexa 488 (1:200; Molecular Probes, Eugene, OR). The sections were embedded with Permafluor (Thermo Shandon, Pittsburgh, PA). We used a confocal microscope (TCS SP2; Leica) to analyze the samples.

Morphological assays. The cells were stimulated for the indicated periods at $37^{\circ} \mathrm{C}$ with $20 \mathrm{ng} / \mathrm{ml}$ BDNF (PeproTech, Rocky Hill, NJ) or 100 $\mathrm{ng} / \mathrm{ml}$ NGF (PeproTech) or vehicle. The cell samples were also incubated for $20 \mathrm{~min}$ with anti-BDNF ( $5 \mu \mathrm{g} / \mathrm{ml}$; Santa Cruz Biotechnology) and then were incubated for $30 \mathrm{~min}$ with $20 \mathrm{ng} / \mathrm{ml}$ BDNF. For treatment with Toxin A (Biogenesis, Poole, UK) and C3 toxin (Calbiochem, La Jolla, $\mathrm{CA}$ ), we performed the procedures according to methods described previously (Just et al., 1995; Maekawa et al., 1999). Toxins (20 ng/ml of
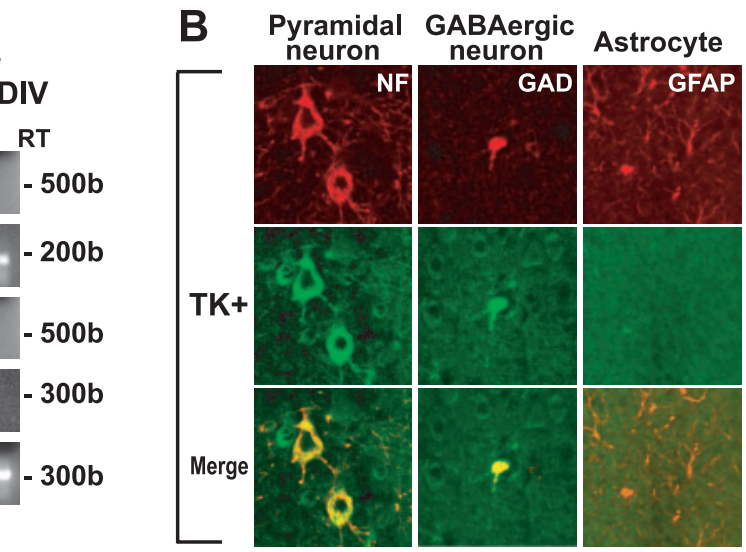

$-300 \mathrm{~b}$

$-300 b$

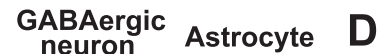

D
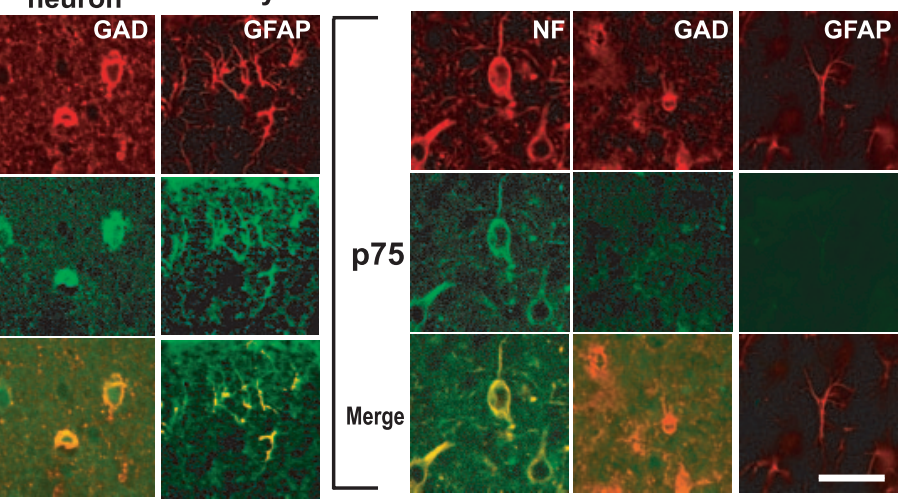

Figure 3. Expression of BDNF receptors in astrocytes in primary culture and young adult rat brain. $A, \mathrm{RT}-\mathrm{PCR}$ analysis of TrkB subtypes and anti-GFAP (GFAP), respectively, are shown in red. The immunopositive structures of TK+, T1, and p75 are shown in green. The

Toxin A, $30 \mu \mathrm{g} / \mathrm{ml}$ of C 3 toxin) were added to the 30 DIV cells, and the cells were incubated for $24 \mathrm{~h}$ at $37^{\circ} \mathrm{C}$. The cells were washed twice in PBS and then were fixed in 4\% formaldehyde in PBS for $1 \mathrm{~h}$ at room temperature. The cells were preincubated with PBS-GB and were incubated with anti-GFAP for $48 \mathrm{~h}$ at $4^{\circ} \mathrm{C}$. After being washed in PBS, the cells were incubated with anti-mouse IgG Cy3. The cells were then embedded with Permafluor. We used a confocal microscope for the analysis. For the time-lapse analysis, the astrocytic cultures were set on the confocal microscope (TCS SP2; Leica) with oxygen supply. Phase-contrast images were taken using a $40 \times$ water-immersion objective at indicated time. Each cell area was measured by AquaCosmos (Hamamatsu Photonics K.K., Hamamatsu, Japan).

\section{Results}

\section{Rho GDI1 is a T1-binding protein}

T1 exhibits a characteristic developmental expression pattern in the mammalian CNS (i.e., the expression of T1 is known to be remarkably increased after birth and is a major product among TrkB subtypes in adults) (Allendoerfer et al., 1994; Fryer et al., 1996; Ohira et al., 1999). Thus, we purified T1-binding proteins from the cytosolic fraction of adult rat brains, using an affinity column conjugated with the C-terminal-specific sequence of T1. A $28 \mathrm{kDa}$ protein was eluted from the column as a sharp peak under low $\mathrm{pH}$ conditions using glycine buffer, $\mathrm{pH} 2.5$ (Fig. $1 \mathrm{~A}$ ). The fractions containing the protein eluted from the affinity column were concentrated by a centrifugal concentrator. Then, the $28 \mathrm{kDa}$ protein was purified as a single band blotted on a PVDF membrane and cleaved by $\mathrm{CNBr}$. The resulting peptides were 
A
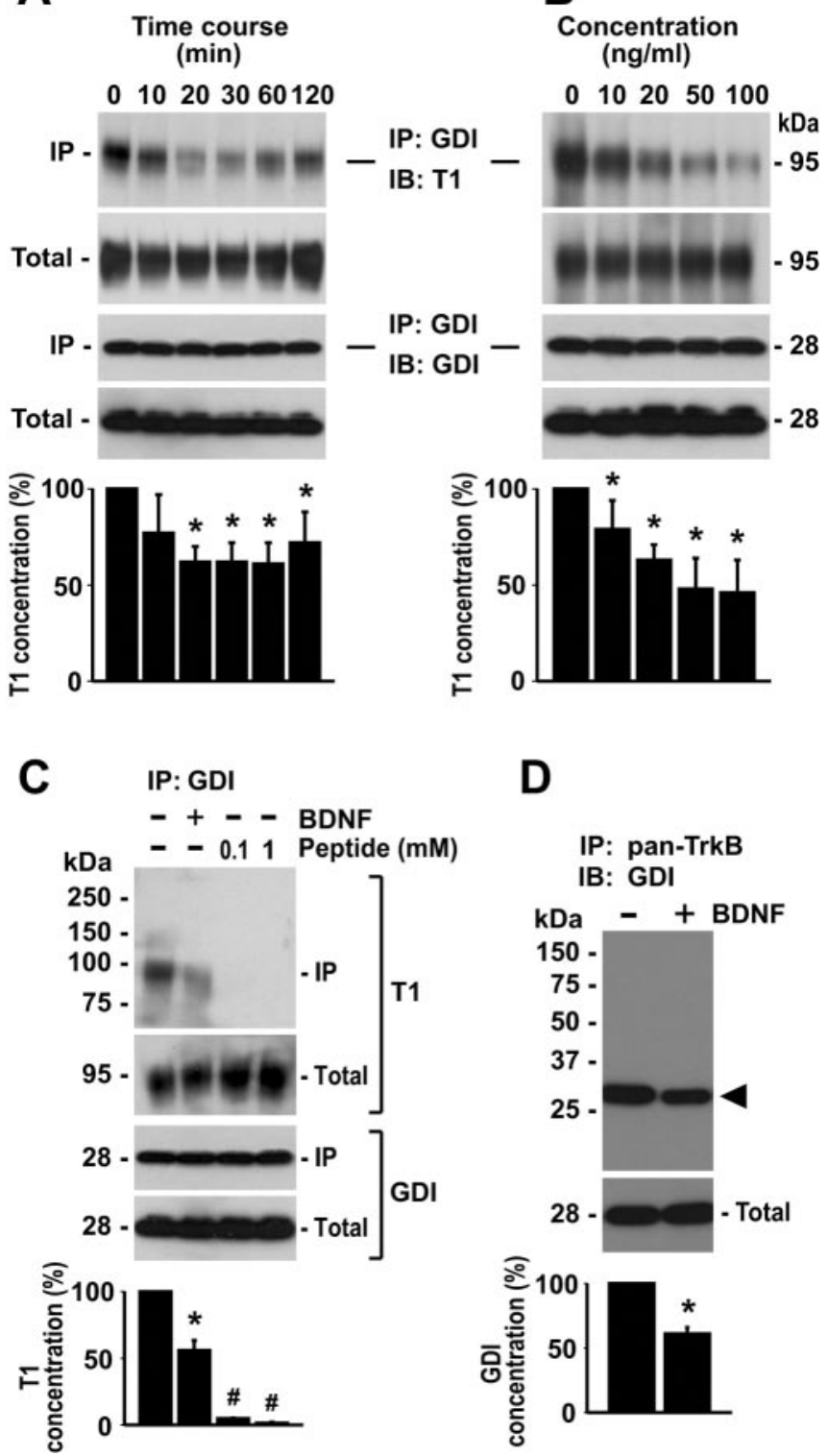

B (ng/mi)

o 102050100 $\mathrm{kDa}$ 95 95 28 28 D

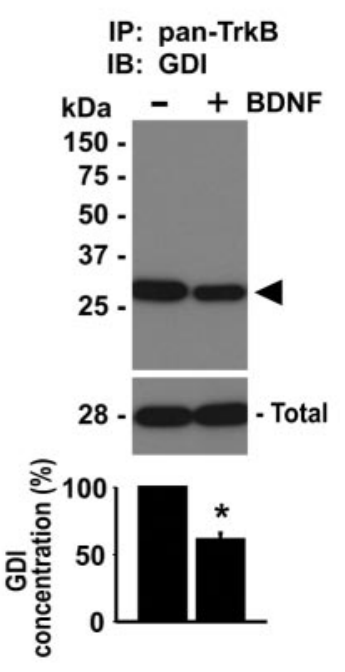

Figure 4. Dissociation of Rho GDI1 from T1 by BDNF treatment in 30 DIV astrocytes. $A$, Coimmunoprecipitation of T1 with anti-Rho GDI1 at each time point after BDNF stimulation (20 $\mathrm{ng} / \mathrm{ml})$. B, Ligand-concentration dependency of the interaction between T1 and Rho GDI1 at 30 min after each concentration of BDNF stimulation. C, Competitive assay using the T1-specific peptides. The synthetic peptides of the T1 C terminal were added to the lysates of 30 DIV astrocytes. At the concentration of $100 \mu \mathrm{m}$ and $1 \mathrm{~mm}$, the T1 bands were hardly observed (lanes 3 and 4). D, Coimmunoprecipitation of Rho GDl1 with anti-pan-TrkB. Astrocytes were stimulated for $30 \mathrm{~min}$ by BDNF $(20 \mathrm{ng} / \mathrm{ml})$. The arrowhead indicates Rho GDI1 ( $28 \mathrm{kDa})$. Quantitative analysis of the bands in $A-D$. The control levels were taken as $100 \%$. The asterisks indicate statistically significant differences ( $p<0.05$; one-way ANOVA and Scheffé's post hoc test). In C, the \# symbol indicates significant differences between the BDNF and the peptide treatments $(p<0.05$; one-way ANOVA and Scheffe's post hoc test). Values are given as means \pm SD of four independent experiments. IB, Immunoblot; IP, immunoprecipitation.

separated by gel electrophoresis and blotted on a PVDF membrane to purify each band. The N-terminal sequence of one peptide was determined as KYIQHT according to the Edman degradation method. Consequently, this sequence was found to match the inner sequence of Rho GDI1, a Rho guanine nucleotide dissociation inhibitor that can stabilize the inactive, GDP-bound form of Rho GTPase (Takai et al., 2001). Western blot analysis identified the $28 \mathrm{kDa}$ protein as Rho GDI1 (Fig. $1 \mathrm{~B}$ ).
In vitro binding assay

To examine whether T1 directly binds to Rho GDI1, we performed an in vitro pull-down assay using recombinant proteins (i.e., the GST-T1-ICD and Rho GDI1). As shown in Figure 2A, the GST moiety did not bind to Rho GDI1, whereas the GST-T1ICD fusion protein precipitated Rho GDI1. The possible contribution of the direct binding of GST-Rho GDI1 to glutathioneSepharose $4 \mathrm{~B}$ as a result of incomplete cleavage could be excluded, because we detected the Rho GDI1 at $28 \mathrm{kDa}$ but not the $54 \mathrm{kDa}$ band of the fusion protein. Therefore, we concluded that $\mathrm{T} 1$ directly binds to Rho GDI1.

\section{Binding motif of T1 with Rho GDI1}

We further determined a specific motif of T1 binding to Rho GDI1 using deletion mutants of the $\mathrm{C}$ terminal of T1. Constructs of 11 lacking its intracellular domain (T1- $\Delta \mathrm{ICD})$ and $\mathrm{T} 1$ deletion mutants lacking the indicated number of amino acids from the C-terminal domain (T1- $\Delta \mathrm{n})$ were transfected into HEK293 cells, and coimmunoprecipitation with anti-Rho GDI1 antibody was performed at $24 \mathrm{~h}$ after transfection. We detected the bands of both T1- $\Delta 3$ and T1- $\Delta 6$ at $\sim 95 \mathrm{kDa}$, which was comparable with those of normal T1 (Fig. 2 B). However, deletion mutants lacking nine or more amino acids were no longer able to bind to Rho GDI1. Thus, the present results suggested that LFH in the T1specific sequence (FVLFHKIPLDG) is responsible for binding to Rho GDI1.

\section{Expression of BDNF receptors in astrocytic primary cultures} and adult rat brains

T1 has been reported to be distributed in both neurons and glia (Frisén et al., 1993; Armanini et al., 1995; Ohira and Hayashi, 2003). In astrocytic primary cultures from the neonatal rat hippocampus, RT-PCR analysis did not reveal the mRNA expression of any of the TrkB subtypes or of p75 at 2 DIV after plating (Fig. $3 A$ ). Astrocytes cultured long-term (30 DIV) expressed T1 mRNA, whereas no TK+, T2, or p75 mRNA expression was detected. We also examined the distribution of $\mathrm{T} 1$ in the adult rat cortex using fluorescent double-staining histochemistry. In this series, the following cell markers were used: neurofilament for pyramidal neurons, GAD for GABAergic neurons, and GFAP for astrocytes. TK + immunoreactivity was localized in both pyramidal and GABAergic neurons but not in astrocytes (Fig. 3B). In contrast, T1 immunoreactivity was detected not only in both pyramidal and GABAergic neurons, but also in the astrocytes (Fig. 3C). The neurotrophin receptor p75 (p75) was only expressed in the pyramidal neurons (Fig. $3 D$ ). Together, these results indicate that astrocytes in the cortex and hippocampus of adult rats possess only $\mathrm{T} 1$ among the known BDNF receptors. Therefore, we used rat hippocampal astrocytes to investigate the signaling mechanism of T1.

\section{Dissociation of Rho GDI1 from T1 in a \\ BDNF-dependent manner}

To determine whether Rho GDI1 dissociated from $\mathrm{T} 1$ in a BDNF-dependent manner in long-term cultured (30 DIV) astrocytes, we performed a pull-down assay of T1 with anti-Rho GDI1 antibody, and we detected T1 using anti-T1 antibody. As shown in Figure $4 A$, the $\mathrm{T} 1$ band was reduced to $\sim 60 \%$ of the control level at $20 \mathrm{~min}$ after BDNF treatment $(20 \mathrm{ng} / \mathrm{ml})$. The reduced levels of T1 bands were maintained for $60 \mathrm{~min}$, and then a less significant reduction in $\mathrm{T} 1$ bands ( $70 \%$ of the control level) was observed at $120 \mathrm{~min}$ after the addition of BDNF. Moreover, the dissociation of Rho GDI1 from T1 appeared to occur in a dose- 
dependent manner (Fig. 4B). We found that $50 \mathrm{ng} / \mathrm{ml}$ BDNF stimulation for 30 min led to the adequate dissociation of Rho GDI1, which then reached a plateau level (50\% of control level).

Furthermore, to determine whether the interaction between T1 and Rho GDI1 was specific, we performed the peptide competition assays using the T1-specific C-terminal peptide. The peptides were added to the lysates derived from 30 DIV astrocytes to a final concentration of 100 $\mu \mathrm{M}$ or $1 \mathrm{~mm}$. Both additions of $100 \mu \mathrm{M}$ and $1 \mathrm{~mm}$ peptides significantly inhibited the interaction (4.7 and 1.4\% of control level, respectively) (Fig. 4C). Because Rho GDI1 was immunoprecipitated by anti-Rho GDI1 in the competitive assays (Fig. 4C, lanes 3 and 4), which was comparable with the control level (Fig. 4C, lane 1), the peptides specifically blocked the $\mathrm{T} 1$ binding to Rho GDI1.

In addition, we performed a pull-down assay of Rho GDI1 using anti-pan-TrkB antibody, and we detected Rho GDI1 using anti-Rho GDI1 antibody; this approach thus reversed the use of the antibodies to confirm the interaction between T1 and Rho GDI1. Then, we found that the Rho GDI1 band was reduced by $60 \%$ of the control level by BDNF treatment (Fig. $4 D$ ), which was comparable with the results of the pull-down assay performed with anti-Rho GDI1. Therefore, these findings suggest that treatment with BDNF can lead to the dissociation of Rho GDI1 from T1. In the subsequent experiments, to obtain sufficient dissociation of Rho GDI1 from T1, we applied $20 \mathrm{ng} / \mathrm{ml}$ BDNF for $30 \mathrm{~min}$ to astrocytic cultures. At the concentration of $20 \mathrm{ng} / \mathrm{ml} \mathrm{BDNF}$, p75 cannot function (Dechant and Barde, 1997), even through p75 expression remained below the levels that could be detected by PCR (Fig. 3A).

\section{BDNF effects on astrocytic morphology} in 30 DIV cultures

Rho GTPases are involved in the regulation of cell morphology by remodeling the cytoskeleton, which contains microfilaments, intermediate filaments, and microtubules (Ridley, 2001; Etienne-Manneville and Hall, 2002). Rho GDI1 has been shown to selectively interact with the GDP-bound forms of the Rho GTPases and to inhibit their conversion from the GDP-bound inactive form to the GTPbound active form (Takai et al., 2001). Thus, we examined the morphological alteration of astrocytes by endogenous $\mathrm{T} 1$ in 30 DIV cultures. In serum-free medium containing $\mathrm{N} 2$ supplement, the form of 30
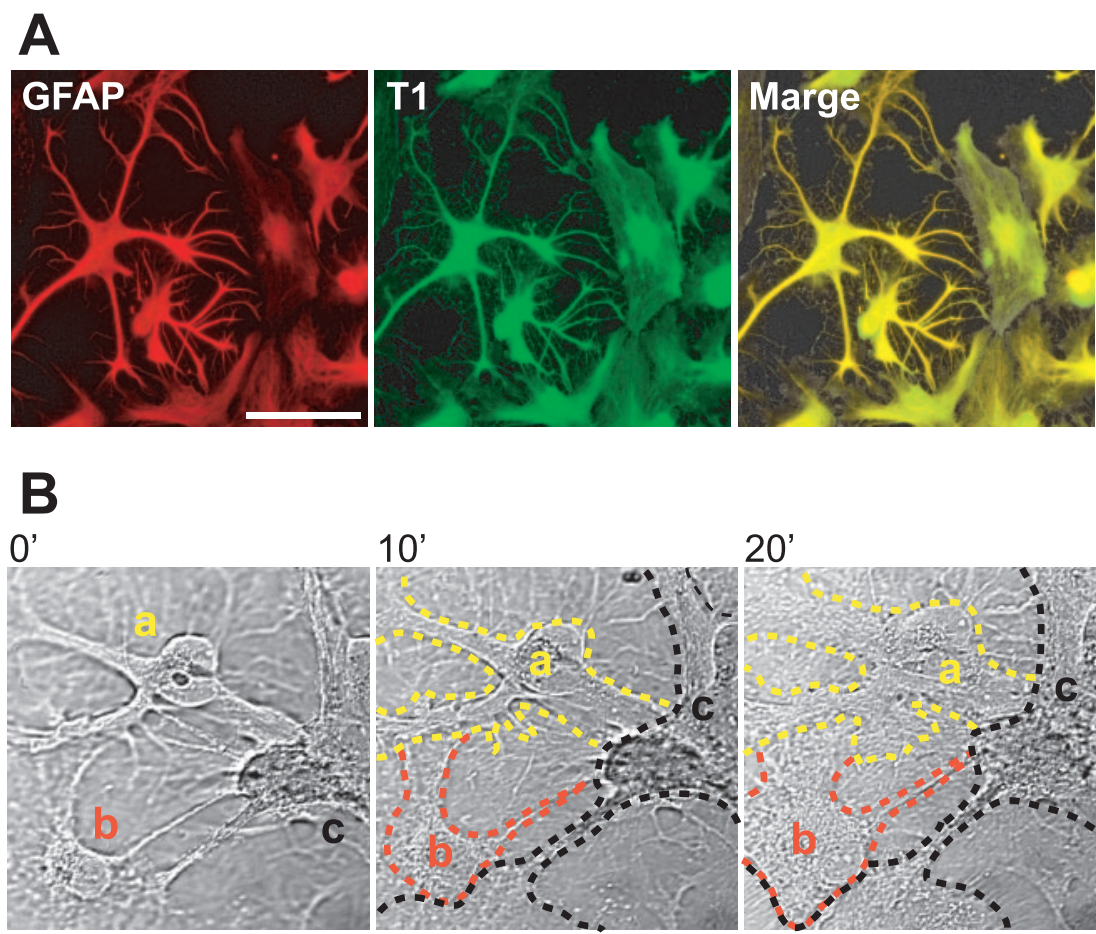

$10^{\prime}$

$20^{\prime}$

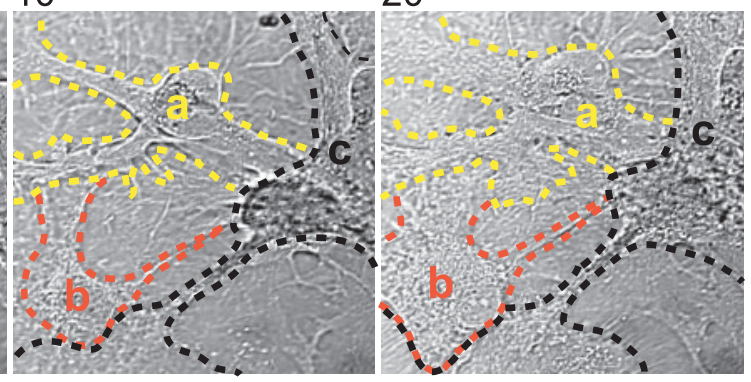

30 '

$60^{\prime}$ $120^{\prime}$
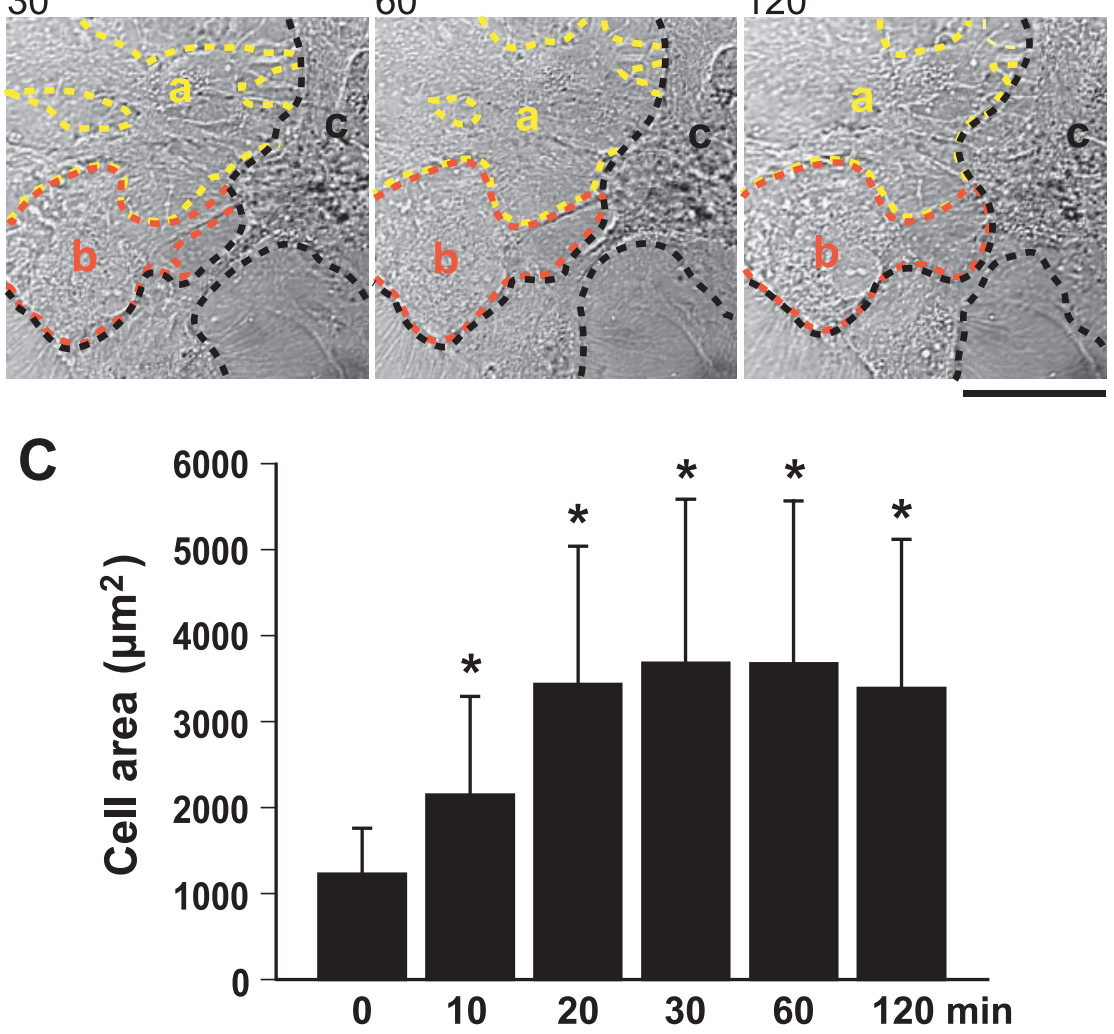

Figure 5. Morphological changes in astrocytes in 30 DIV astrocytic cultures. A, Coexpression of GFAP and T1 in the 30 DIV astrocytes. The cells were incubated in DMEM containing N2 supplement without BDNF stimulation and fixed in 4\% formaldehyde. The immunoreactive cells for GFAP and T1 were stained by red and green, respectively. The cells coexpressing both GFAP and T1 were yellow. Note that almost all cells were coimmunopositive. Scale bar, $50 \mu \mathrm{m}$. B, Time-lapse images of the 30 DIV astrocytic cultures by the phase-contrast microscope. BDNF $(20 \mathrm{ng} / \mathrm{ml})$ was added to the 30 DIV cultures at 0 min. The number in each photograph indicates the time lapse (in minutes) after BDNF treatment. Three cells were marked by the colored small letter, yellow "a," red "b," and black " $c$," and they were also outlined by the dotted lines of corresponding colors. Note that the more the time passed, the thinner the cell bodies and processes were. Scale bar, $20 \mu \mathrm{m}$. C, Quantification of cell size. Values are given as the means \pm SD of the cell size analysis based on the results of four independent experiments (total cell counts: 0 min, $n=944 ; 10$ $\min , n=1003 ; 20 \min , n=978 ; 30 \mathrm{~min}, n=981 ; 60 \mathrm{~min}, n=1105 ; 120 \mathrm{~min}, n=1054)$. The asterisks indicate significant differences ( $p<0.05$; one-way ANOVA and Scheffé's post hoc test) compared with the value at $0 \mathrm{~min}$. 


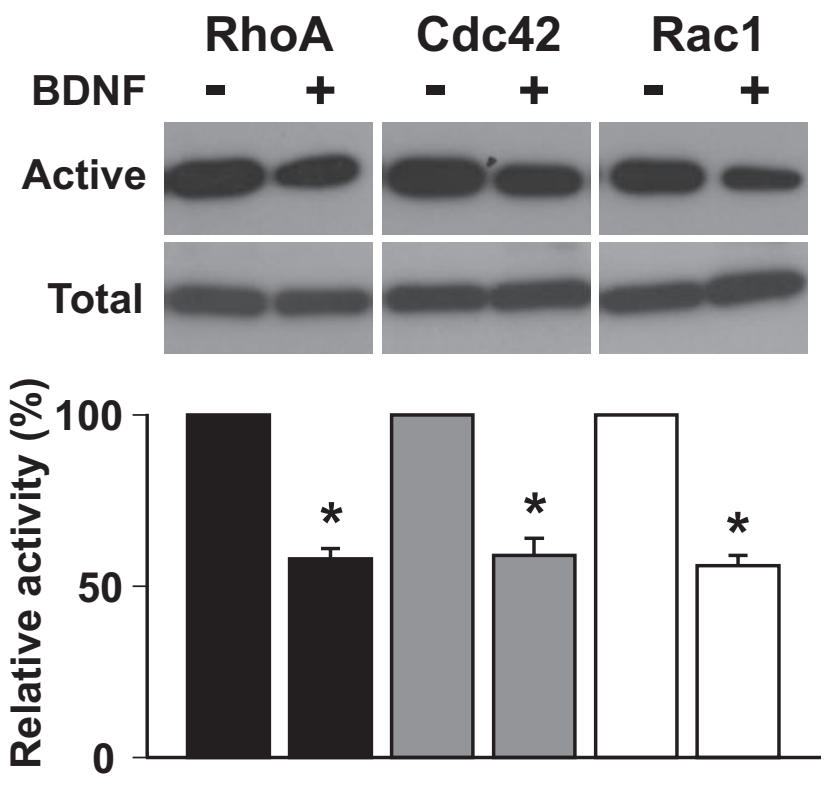

Figure 6. Activities of Rho GTPases in 30 DIV astrocytic cultures. Top, The cells were stimulated for 30 min with BDNF $(20 \mathrm{ng} / \mathrm{ml})$, and the cell extracts were subjected to in vitro binding assays. The precipitates and total proteins ( $5 \mu \mathrm{g}$ for RhoA; $100 \mu \mathrm{g}$ for $\mathrm{Cd}(42$ and Rac1) were loaded on $15 \%$ gel and were detected with specific antibodies. Bottom, Quantitative analysis of the bands shown in the above images. Each control level, without BDNF stimulation, was taken as $100 \%$. The asterisks indicate statistically significant differences $(p<0.05$; paired Student's $t$ test). Values are given as means $\pm S D$ of four independent experiments.

DIV astrocytes became fibrous (Fig. $5 A, B$ ). Almost all astrocytes were immunoreactive for both GFAP and T1 (Fig. 5A). The timelapse analysis showed that BDNF stimulation led to a dynamic change in the shape of the astrocytes from fibrous to flat within 30 min (Fig. 5B). The cell surface area significantly increased 1.7fold at $10 \mathrm{~min}$ and reached a threefold plateau level at $30 \mathrm{~min}$ (Fig. $5 C)$. At 120 min after BDNF stimulation, the cells had decreased in size, albeit not significantly. At the same time, we measured the activities of RhoA, Rac1, and Cdc42, which are substrates of Rho GDI1, at $30 \mathrm{~min}$ when the change in astrocytic morphology reached a maximum. The active forms of all Rho GTPases were reduced by $60 \%$ of the control level (Fig. 6). The observed alterations in the shape of the astrocytes and the changes in Rho GTPase activity were both closely associated with the interaction between T1 and Rho GDI1 (Fig. 4), suggesting that BDNF-T1Rho GDI1 signaling might control the Rho GTPases and consequently alter astrocytic morphology.

To elucidate the mechanism by which Rho GTPases regulate astrocytic morphology, we performed an inhibition assay of Rho GTPases using Toxin A and C3 toxin, which are known to inhibit all Rho GTPases (RhoA, Cdc42, and Rac1) and RhoA, respectively, in 30 DIV cultures. The astrocytic cultures were stimulated by BDNF at $20 \mathrm{ng} / \mathrm{ml}$ for $30 \mathrm{~min}$. The results of the control cells were the same as the time-lapse analysis above (Fig. 7A). The astrocytes without BDNF treatment had long processes. Being treated by BDNF, the shapes of astrocytes were flat. In the Toxin A-treated cultures, the morphology of astrocytes was flat, regardless of BDNF treatment (Fig. 7A), which was similar to the shapes of the BDNF-treated control cells. The size of the cells was the same as that of BDNF-treated normal astrocytes (Fig. $7 B$ ). In contrast, $\mathrm{C} 3$ toxin treatment left the astrocytic morphology fibrous with fine filopodia-like processes (Fig. 7A). After BDNF treatment, the cells flattened; these findings were comparable with the observed morphology and size of the BDNF-treated con- trol cells and the Toxin A-treated cells (Fig. 7A). Therefore, endogenous T1 might alter astrocytic morphology (i.e., it renders astrocytes fibrous and flat) via the control of Rho GTPases and primarily through Cdc42 and Rac.

Involvement of $\mathrm{T} 1$ in the regulation of astrocytic morphology We examined the molecular mechanism of the T1-induced morphological alteration of astrocytes by performing a transfection assay with T1 mutants. Because 30 DIV astrocytes were refractory to transfection $(<5 \%)$, whereas short-term cultured astrocytes $(2$ DIV) were easily transfected at high transfection efficiencies $(>90 \%)$, we used 2 DIV astrocytes, in which we observed no expression of BDNF receptors (Fig. 3A).

First, we examined the effect of BDNF on the morphology of astrocytes overexpressing normal T1 or a T1 deletion mutant. Both the untransfected control cells and empty vector (GFP)transfected cells showed a flat polygonal morphology with processes (Fig. 8). When these cells were treated with BDNF (20 $\mathrm{ng} / \mathrm{ml}$ ) for $30 \mathrm{~min}$, we observed no changes in the cell morphology. On the other hand, the T1-transfected cells exhibited a fibrous, spindle morphology with long and narrow processes, even under the no-treatment condition. Interestingly, BDNF treatment rapidly and remarkably altered the cell morphology. Only 30 min after treatment with BDNF, the cells exhibited flat and wide cell bodies and stretched-out GFAP-positive fibers. The relative cell area of T1-transfected astrocytes treated with BDNF increased significantly, about fivefold, compared with that of T1transfected astrocytes without BDNF treatment (Fig. 8 B). In contrast, when T1- $\Delta 11$, a deletion mutant of a T1-specific sequence (Fig. 2 B), was transfected, the cell morphology observed was a flat polygon with processes similar to those of the control, and BDNF treatment was not found to induce any morphological changes such as those found in the T1-transfected cells. Recently, p75 has been reported to associate with Rho GDI1 and regulate Rho activity (Yamashita et al., 1999; Yamashita and Tohyama, 2003). However, high-concentration treatment with NGF (100 ng/ml), which is a p75 ligand, had no effect on cell morphology. Taken together with the evidence that there was no morphological change in nontransfected cells or in GFP-expressing cells, it was concluded that p75 had no effect on cell morphology.

Next, we investigated whether BDNF negatively regulates the Rho GTPases through Rho GDI1 released from T1. To this end, we performed a pull-down assay of the active forms of the Rho GTPases. In astrocytes expressing exogenous T1, BDNF treatment was found to reduce the amount of activated RhoA, Cdc42, and Rac1 by 55, 51, 55\% of the control level, respectively (Fig. 9). In contrast, cells expressing T1- $\Delta 11$ and cells treated with NGF $(100 \mathrm{ng} / \mathrm{ml})$ were not associated with a decrease in the active forms of RhoA, Cdc42, and Racl. These results are compatible with findings regarding the regulation of Rho GTPase activity by endogenous T1 (Fig. 6). Thus, the present results suggest that the specific C-terminal alignment of T1 is necessary for the control of Rho GTPases and for the observed morphological alteration of astrocytes.

\section{Competitive assay with $\mathrm{T} 1$ intracellular peptides}

We then investigated the effects of the T1-specific C-terminal peptide on the regulation of astrocytic morphology. To inhibit the $\mathrm{T} 1$ signaling cascade in a competitive manner, we cotransfected the expression vectors of T1 and each of the following: CFP, CFP- $\Delta 11$, and CFP-ICD. We expected that CFP-ICD, but not CFP or CFP- $\Delta 11$, would trap Rho GDI1 within the cytoplasmic region and inhibit the association of Rho GDI1 to the Rho 
GTPases, thereby resulting in the inhibition of the activity of BDNF. As shown in Figure 10, $A$ and $B$, when both CFP and CFP- $\Delta 11$ were transfected with normal T1, we observed fibrous astrocytes under the condition lacking BDNF treatment. The addition of BDNF induced the morphological alteration of the astrocytes from fibrous to flat for $30 \mathrm{~min}$. Namely, neither CFP nor CFP- $\Delta 11$ blocked the effects of BDNF, compared with the results obtained with the transfectant with T1-expression vector alone (Fig. 8). On the other hand, when CFP-ICD was overexpressed, the cells exhibited the same fibrous characteristics as were observed in the cases of the CFP- and CFP- $\Delta 11$ transfected cultures. However, BDNF treatment was not found to induce morphological changes among the astrocytes that remained fibrous. Therefore, the T1-specific sequence was determined to be indispensable for the morphological alteration of these astrocytes.

\section{Discussion}

In the present study, we demonstrated that (1) a truncated TrkB receptor, T1, is capable of ligand-mediated signaling via Rho GDI1, which acts as a negative inhibitor in the Rho signaling cascade, and (2) the T1 signaling cascade regulates glial cellular morphology. A schematic representation is shown in Figure 10C. Our findings clearly indicate that $\mathrm{T} 1$ is not only the dominant-negative form of $\mathrm{TK}+$, but is also the active receptor of BDNF itself.

\section{Interaction between $\mathrm{T} 1$ and Rho GDI1}

The in vitro binding analysis clearly showed the direct binding of Rho GDI1 and T1 (Fig. 2). One would question what fraction of T1 and Rho GDI1 contributes to the association between $\mathrm{T} 1$ and Rho GDI1. In the Western blot analysis in Figure 4 , we loaded the $100 \mu$ g total protein per lane for $\operatorname{TrkB}$, which is approximately one-third amount of total protein in each lysate derived from a $3 \mathrm{~cm}$ dish. As shown in Figure $4 A-C$, the level of the precipitated $\mathrm{T} 1$ in the control (at $0 \mathrm{~min}$ or no addition of $\mathrm{BDNF}$ ) is comparable with the total level. In addition, in this study, the immunoprecipitations with anti-GDI or anti-pan-TrkB were performed with an efficiency of $\sim 30 \%$. The one-fourth of each precipitate was loaded on SDS-PAGE. Therefore, $44 \%$ of total T1 in an astrocyte bind to Rho GDI1.

In Figure $4 D, \sim 1 / 60$ amount of total protein in each lysate ( 5 $\mu \mathrm{g}$ total protein per lane) for Rho GDI1 was loaded on each lane. As described above about T1, we calculated the fraction of Rho GDI1 in the interaction between T1 and Rho GDI1. Consequently, $\sim 2.2 \%$ of total Rho GDI1 in an astrocyte is involved in the binding to T1. It is a big surprise for us that the drastic change of astrocytic morphology is attributable to the low percentage of Rho GDI1 associating with T1. Rho GTPases are implicated in the
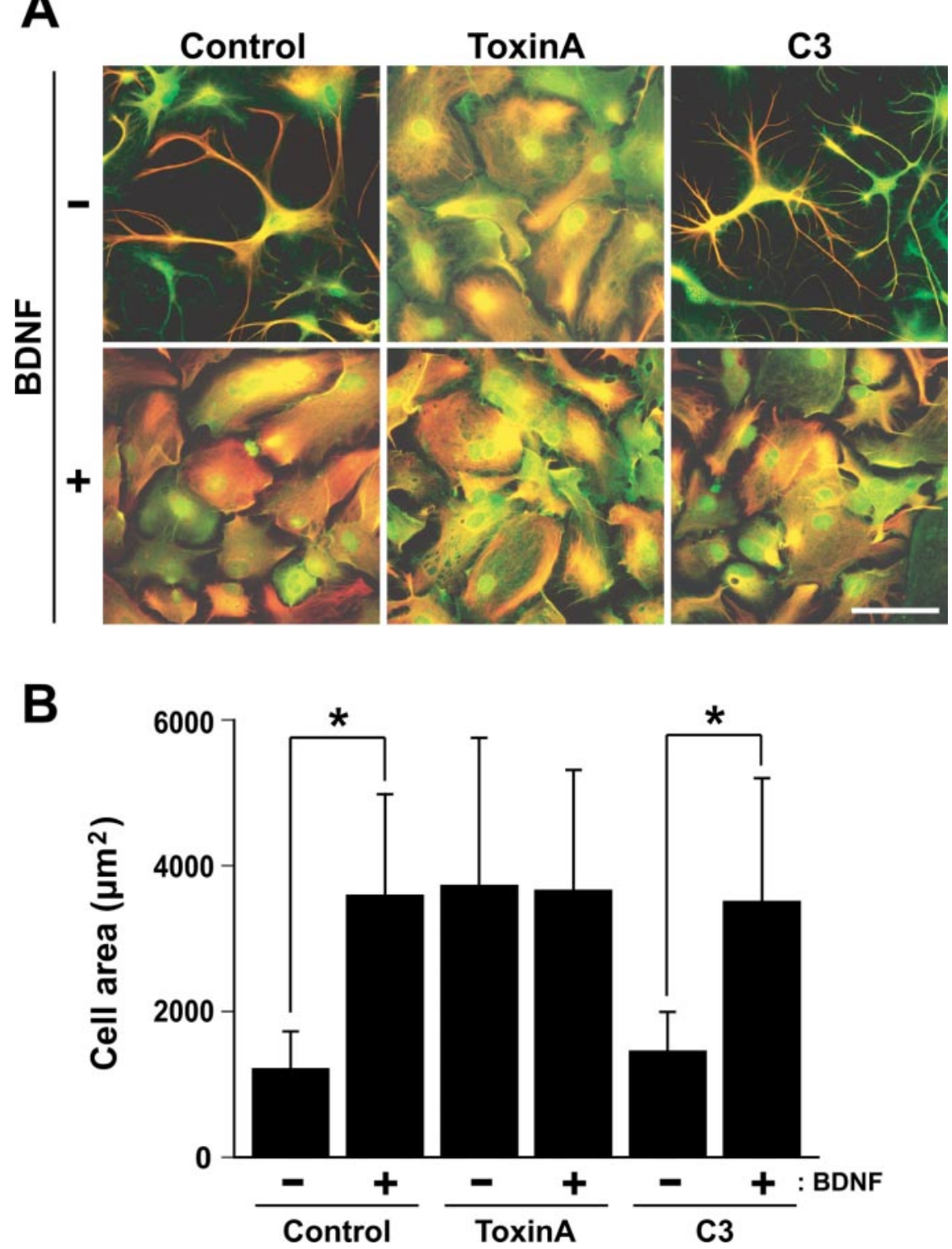

Figure 7. Morphological changes in astrocytes treated with Toxin A and C 3 in 30 DIV astrocytic cultures. A, The images of cells treated by nothing (control), Toxin A, and C3. The 30 DIV astrocytes were incubated with Toxin A ( $20 \mathrm{ng} / \mathrm{ml})$ or C3 $(30 \mu \mathrm{g} / \mathrm{ml})$ for $24 \mathrm{~h}$. After being washed with serum-free medium, BDNF $(20 \mathrm{ng} / \mathrm{ml})$ was added to the cells, which were then fixed in $4 \%$ formaldehyde. The cells were stained with anti-T1 (green) and anti-GFAP (red). All displays show merged images (yellow). Scale bar, $50 \mu \mathrm{m}$. B, Quantitative with BDNF, $n=991$; Toxin A, without BDNF, $n=948$, with BDNF, $n=1064 ;(3$, without BDNF, $n=1055$, with BDNF, $n=1072)$. The asterisks indicate statistically significant differences ( $p<0.05$; paired Student's $t$ test).

important cell functions via remodeling cytoskeleton such as proliferation, migration, elongation of neurites, and membrane trafficking, suggesting that Rho GTPases are strictly regulated. Therefore, Rho GDI1 as a regulator of Rho GTPases are also severely controlled. Then, Rho GDI1 regulated by T1 may be small amount. A part of the rest of Rho GDI1 may be interacted with ERM consisting of ezrin, radixin, and moesin (Sasaki and Takai 1998) and might be bound to other unknown proteins.

\section{Interaction between $\mathrm{T} 1$ and other proteins}

p75 has been reported to control the activity of RhoA in a Rho GDI1-dependent manner (Yamashita et al., 1999; Yamashita and Tohyama, 2003). In the present study, we demonstrated that T1 also binds directly to Rho GDI1 and that LFH residues in the T1-specific sequence is important for this type of binding. Be- 

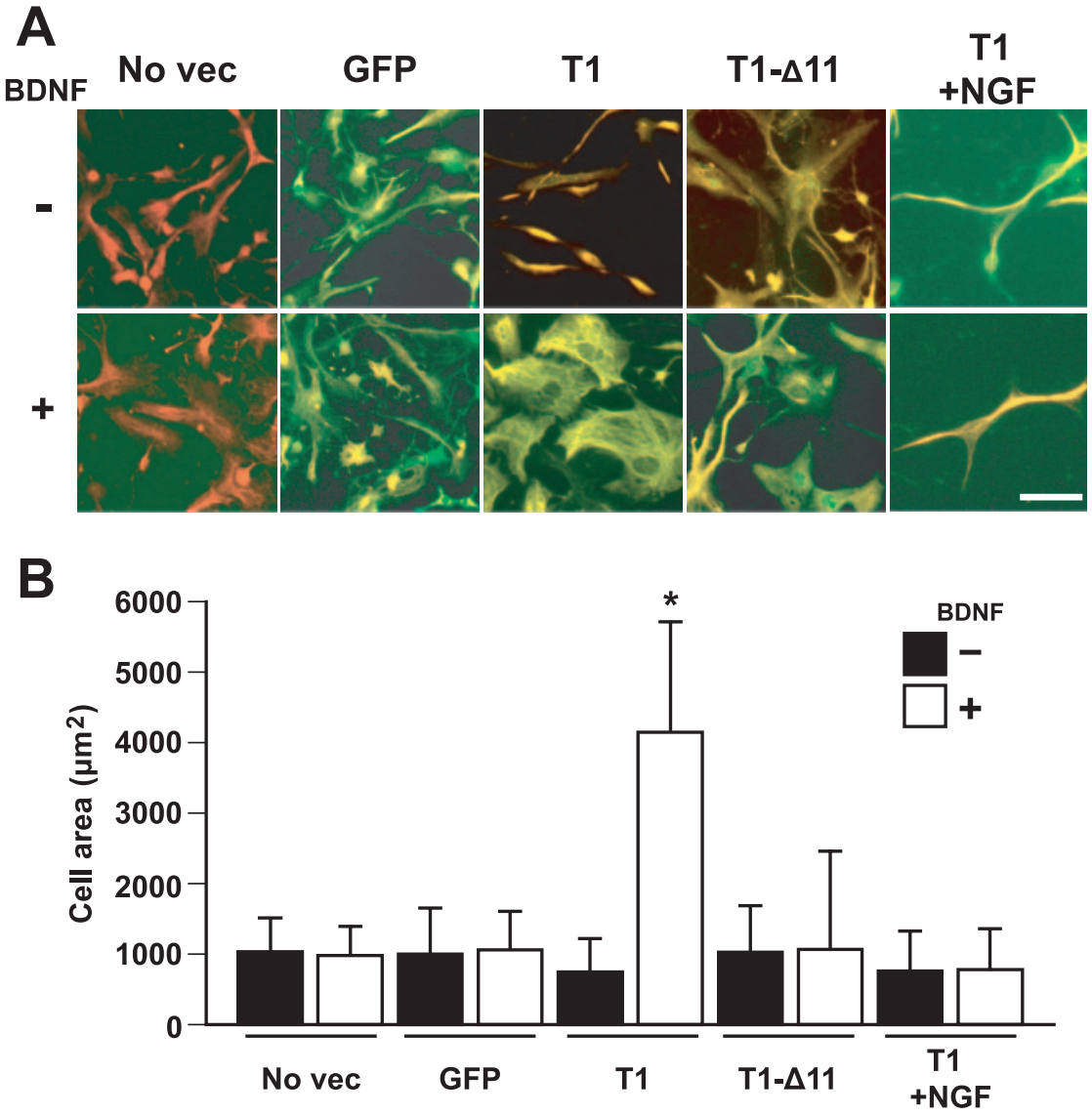

Figure 8. Morphological changes in astrocytes in 2 DIV cultures. A, No Vec, No transfection; GFP, EGFP; T1, normal T1; T1- $\Delta 11$, a deletion form of the T1-specific sequence (see Fig. $2 B$ ); T1 + NGF, normal T1-expressing cells that were treated with $100 \mathrm{ng} / \mathrm{ml}$ NGF instead of with BDNF. The cells were stimulated with vehicle $(-)$ or with $20 \mathrm{ng} / \mathrm{ml} \mathrm{BDNF}(+)$ and then were stained with anti-GFAP. Almost all of the cells were double positive for GFP (green) and GFAP (red), except for the No Vec cells. All displays show merged images (yellow-green). Scale bar, $30 \mu \mathrm{m}$. B, Quantification of cell size in $A$. Values are given as the means \pm SD from the results of four independent experiments (total cell counts: No Vec, without BDNF, $n=854$, with BDNF, $n=821$; GFP, without BDNF, $n=879$, with BDNF, $n=787$; T1, without BDNF, $n=698$, with BDNF, $n=731$; T1- $\Delta 11$, without BDNF, $n=687$, with BDNF, $n=634 ; \mathrm{T} 1+\mathrm{NGF}$, without BDNF, $n=810$, with BDNF, $n=834)$. The asterisks indicate significant differences ( $p<$ 0.05; one-way ANOVA and Scheffé's post hoc test) from the values obtained without BDNF treatment.

cause LFH is not contained in the intracellular domain of p75, both $\mathrm{T} 1$ and p75 may bind different regions of Rho GDI1.

Recently, Kryl and Barker (2000) reported that truncated TrkBinteracting protein (TTIP) is isolated from $15 \mathrm{~N}$ neuroblastoma cells by using coimmunoprecipitation with GST fusion protein containing the intracellular juxtamembrane. TTIP has a molecular weight of $61 \mathrm{kDa}$, and T1 peptide competitively interrupted TTIP binding to T1, suggesting the direct binding interaction between them. However, the BDNF stimulation cannot modulate the interaction between T1 and TTIP. Kryl and Barker (2000) also analyzed TTIP by using matrix assisted laser desorption/ionization-mass spectrometry and described that TTIP is an unique protein. It is uncertain whether Rho GDI1 and TTIP bind directly to the different motifs in the T1-specific region or compete the same binding site. T1-mediated signaling may depend on its cellular compartment, because a fraction of T1 binds Rho GDI1. On the other hand, we detected proteins of 50,60, and $72 \mathrm{kDa}$ eluted from an affinity column (Fig. 1A); however, the correlation of each of these proteins with TTIP remains to be clarified.

Regulation of Rho proteins and astrocytic morphology by $\mathrm{T} 1$ The T1-interacting protein, Rho GDI1, is an inhibitory regulator of the Rho GTPases: Rho GDI1 is able to inhibit the activation of
RhoA, Cdc42, and Rac1. On the other hand, the Rho GTPases are involved in the remodeling of the actin cytoskeleton: RhoA is involved in the formation of stress fibers; activated Cdc42 and Rac1 lead to lamellipodia and cell spreading, whereas activated Cdc42 induces filopodia (Hall, 1998). In this study, we demonstrated that Rho GDI1 released from T1 decreased the activities of the Rho GTPases, RhoA, Cdc42, and Rac1. However, it has remained unclear which Rho protein is related to the morphological changes in astrocytes triggered by BDNF. All Rho GTPases are known to be inhibited by Toxin A, and the form of astrocytes treated with Toxin A became flat. In contrast, the addition of C3, an inhibitor of RhoA, led to the formation of fibrous astrocytes with fine processes. Therefore, we were able to distinguish at least three types of morphology in this experiment. In the first type, the astrocytes became flat when all Rho GTPases were inhibited (Toxin A in Fig. 7A). In the second type, when only RhoA was inhibited by $\mathrm{C} 3$, the morphology of the cells was fibrous (C3 in Fig. 7A), which differed from the morphology of 30 DIV cells before the addition of BDNF (at 0 min in Fig. $5 A$ and control in Fig. 7A), and the morphology of the fibrous cells also differed from that of T1-expressing 2 DIV cells (T1 in Fig. 8A). In the C3-treated condition, the processes of the astrocytes resembled filopodia; that is, fine processes extended from the bold processes of the astrocytes and the cell bodies (C3 in Fig. 7A). In the third type, the cells were not as fibrous as the second type of cell when the activities of the Rho GTPases remained at their basal levels. Typically, 30 DIV and T1-overexpressing astrocytes had spindle-shaped bodies or small, flat cell bodies and long processes (Figs. 5A, 7A, 8A). Thus, it appears that BDNF-T1 signaling suppressed the activity of all three Rho proteins and then induced morphological change leading to the flat type 1 cells. In addition, the cell flattening appears to be mediated primarily by the suppression of Cdc42 and Rac. In this context, it should be emphasized that extension of the astrocyte cell bodies was observed as a result of the inhibition of the Rho GTPases by T1-Rho GDI1 signaling. Recent studies have shown that the Rho GTPases control the remodeling of microfilaments, intermediate filaments, and microtubules (Ridley, 2001; Etienne-Manneville and Hall, 2002). Therefore, the regulation of cell morphology is not solely dependent on the microfilaments but instead depends on the well orchestrated control of various cytoskeletal proteins. More precise information regarding the mechanism of their regulation by BDNF remains to be obtained by additional study.

\section{Functional role of $\mathrm{T} 1$ in astrocytes}

In the present study, we demonstrated that astrocytes are able to alter their morphology rapidly and dramatically via the T1 $>$ Rho GDI1 > Rho GTPase signaling cascade in a BDNF-dependent manner. In the mature mammalian CNS, BDNF is synthesized and secreted from presynaptic and/or postsynaptic sites, depend- 
ing on neural activity (Fawcett et al., 1998; Aloyz et al., 1999; Hartmann et al., 2001; Kohara et al., 2001). Thus, astrocytic morphological changes might take place in an activity-dependent manner. On the other hand, recent studies have reported that glial morphology is drastically altered to maintain the clearance of neurotransmitters and to maintain the neural network and neural plasticity (Iino et al., 2001; Oliet et al., 2001; Hirrlinger et al., 2004). In addition, calcium entry into astrocytes has been assumed to be important for the modulation of synaptic transmission (Araque et al., 1999). More recently, T1 has been shown to mediate BDNF-induced calcium signaling in astrocytes (Rose et al., 2003; for review, see Kovalchuk et al., 2004). Although it remains unclear whether or not the entry of calcium into astrocytes can induce the alteration of astrocytic morphology, a mechanism involving the Rho GTPases might be associated with the entry of calcium into astrocytes (Illenberger et al., 1998; Ghisdal et al., 2003; Mehta et al., 2003). Thus, morphological changes attributable to the T1 signaling cascade in astrocytes surrounding synapses may modulate neuron-glial interactions as well as local calcium buffering effects, which would eventually lead to rapid changes in synaptic transmission. The relationship between the T1 signaling cascade and the entry of calcium into astrocytes appears to require additional examination.

\section{References}

Allendoerfer KL, Cabelli RJ, Escanòn E, Kaplan DR, Nikolics K, Shatz CJ (1994) Regulation of neurotrophin receptors during the maturation of the mammalian visual system. J Neurosci 14:1795-1811.

Aloyz R, Fawcett JP, Kaplan DR, Murphy RA, Miller FD (1999) Activity-dependent activation of TrkB neurotrophin receptors in the adult CNS. Learn Mem 6:216-231.

Araque A, Parpura V, Sanzgiri RP, Haydon PG (1999) Tripartite synapses: glia, the unacknowledged partner. Trends Neurosci 22:208-215.

Armanini MP, McMahon SB, Sutherland J, Shelton DL, Phillips HS (1995) Truncated and catalytic isoforms of trkB are co-expressed in neurons of rat and mouse CNS. Eur J Neurosci 7:1403-1409.

Barbacid M (1994) The Trk family of neurotrophin receptors. J Neurobiol 25:1386-1403.

Baxter GT, Radeke MJ, Kuo RC, Makrides V, Hinkle B, Hoang R, MedinaSelby A, Coit D, Valenzuela P, Feinstein SC (1997) Signal transduction mediated by the truncated trkB receptor isoforms, trkB.T1 and trkB.T2. J Neurosci 17:2683-2690.

Bibel M, Barde YA (2000) Neurotrophins: key regulators of cell fate and cell shapes in the vertebrate nervous system. Genes Dev 14:2919-2937.

Biffo S, Offenhäuser N, Carter BD, Barde YA (1995) Selective binding and internalization by truncated receptors restrict the availability of BDNF during development. Development 121:2461-2470.

Dechant G, Barde YA (1997) Signalling through the neurotrophin receptor p75 ${ }^{\text {NTR }}$. Curr Opin Neurobiol 7:413-418.

Eide FF, Vining ER, Eide BL, Zang K, Wang XY, Reichardt LF (1996) Naturally occurring truncated trkB receptors have dominant inhibitory effects on brain-derived neurotrophic factor signaling. J Neurosci 16:3123-3129.
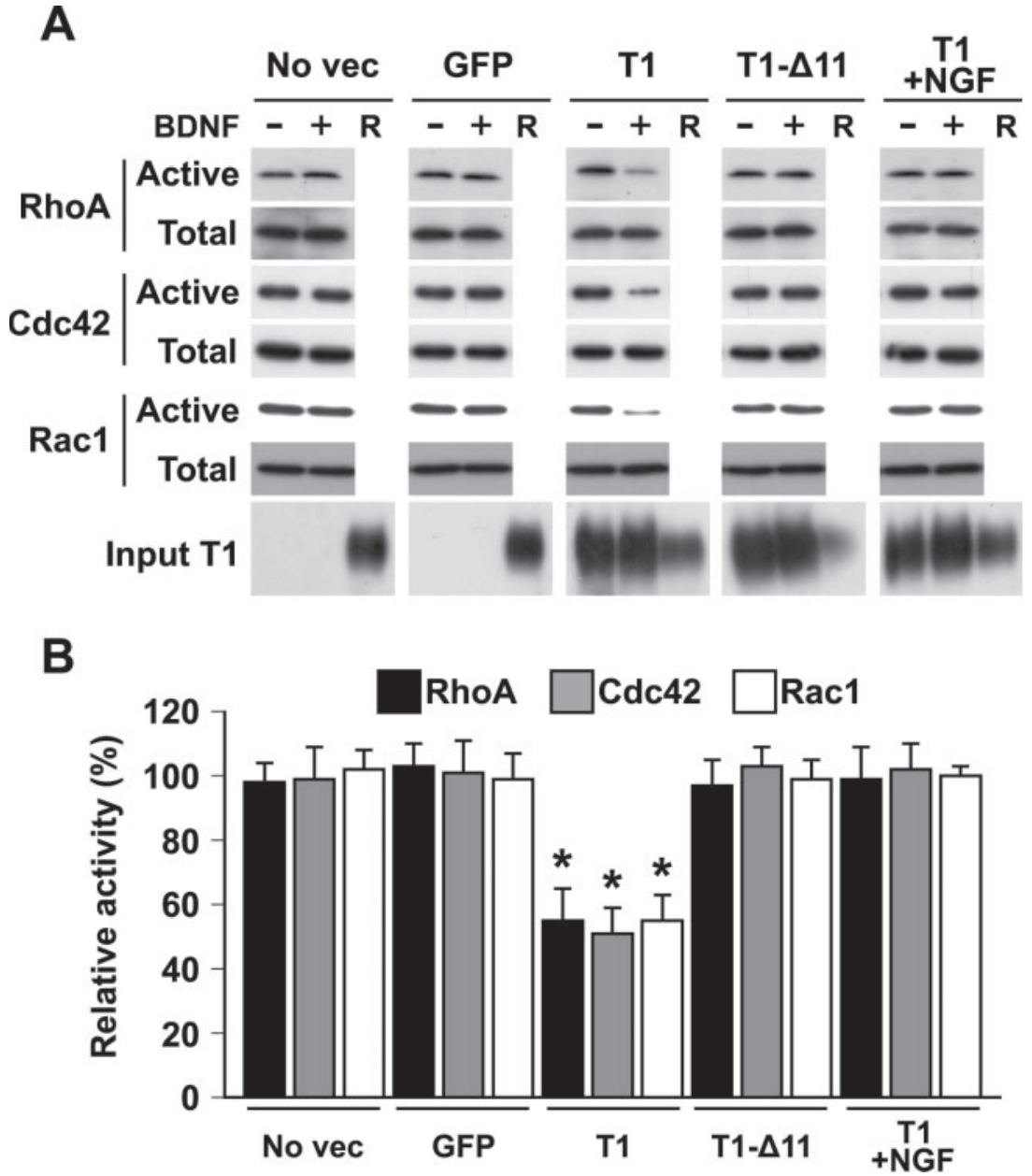

Figure 9. Activities of Rho GTPases in 2 DIV astrocytic cultures. A, No vec, No transfection; GFP, EGFP; T1, normal T1; T1- $\Delta 11$, etion form of T1 (see Fig. 10); T1 + NGF, normal T1-expressing cells that were treated with $100 \mathrm{ng} / \mathrm{ml}$ NGF instead of BDNF. 作 ontrol level, without BDNF stimulation, was taken as $100 \%$. The asterisks indicate statistically significant differences $(p<0.05$; paired Student's $t$ test). Values are given as the means \pm SD of four independent experiments.

Etienne-Manneville S, Hall A (2002) Rho GTPases in cell biology. Nature 420:629-635

Fawcett JP, Bamji SX, Causing CG, Aloyz R, Ase AR, Reader TA, McLean JH, Miller FD (1998) Functional evidence that BDNF is an anterograde neuronal trophic factor in the CNS. J Neurosci 18:2808-2821.

Frisén J, Verge VM, Fried K, Risling M, Persson H, Trotter J, Hökfelt T, Lindholm D (1993) Characterization of glial trkB receptors: differential response to injury in the central and peripheral nervous systems. Proc Natl Acad Sci USA 90:4971-4975.

Fryer RH, Kaplan DR, Feinstein SC, Radeke MJ, Grayson DR, Kromer LF (1996) Developmental and mature expression of full-length and truncated TrkB receptors in the rat forebrain. J Comp Neurol 374:21-40.

Ghisdal P, Vandenberg G, Morel N (2003) Rho-dependent kinase is involved in agonist-activated calcium entry in rat arteries. J Physiol (Lond) 551:855-867.

Haapasalo A, Koponen E, Hoppe E, Wong G, Castrén E (2001) Truncated trkB.T1 is dominant negative inhibitor of trkB.TK+-mediated cell survival. Biochem Biophys Res Commun 280:1352-1358.

Hall A (1998) Rho GTPases and the actin cytoskeleton. Science 279:509-514.

Hartmann M, Heumann R, Lessmann V (2001) Synaptic secretion of BDNF after high-frequency stimulation of glutamatergic synapses. EMBO J 20:5887-5897. 
A

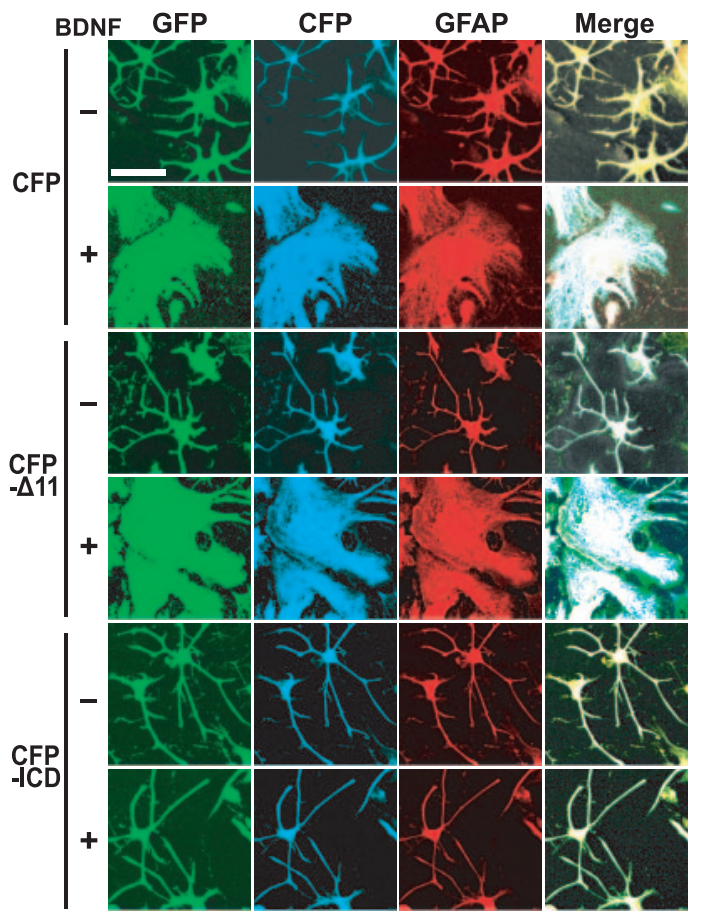

B

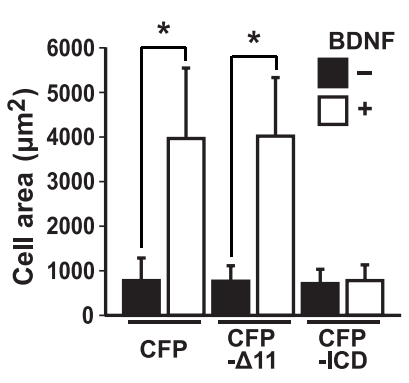

C

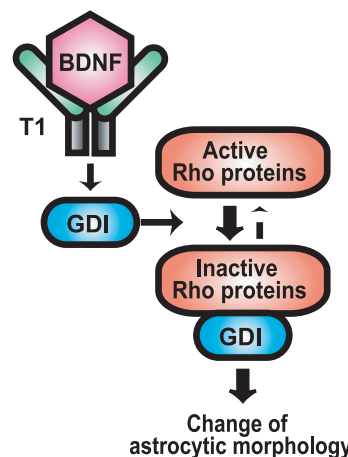

Figure 10. Competitive assay by overexpression of T1-specific C-terminal peptides. A, Expression vectors of T1 and CFP, CFP- $\Delta 11$, or CFP-ICD were cotransfected into astrocytes. CFP- $\Delta 11$ is a CFP-ICD lacking the 11 C-terminal amino acid residues. CFP-ICD is a fusion protein of CFP and the ICD segment of T1. The cells were stimulated with vehicle $(-)$ or with $20 \mathrm{ng} / \mathrm{ml}$ BDNF $(+)$. The cells with three overlapping colors are shown here in white. Scale bar, $50 \mu \mathrm{m}$. B, Quantification of each astrocytic area in $A$. Values are given as the means $\pm S D$ from the results of four independent experiments (total cell counts: CFP, without BDNF, $n=859$, with BDNF, $n=948$; CFP- $\Delta 11$, without BDNF, $n=835$, with BDNF, $n=960$; (FP-ICD, without BDNF, $n=913$, with BDNF, $n=955)$. The asterisks indicate significant differences ( $p<0.05$; one-way ANOVA and Scheffé's post hoc test) from the values obtained without BDNF. C, Simplified schematic of the T1 signaling cascade. In astrocytes, the T1 signaling cascade acts as a negative inhibitor of the Rho GTPases in a BDNF-dependent manner, resulting in the morphological alteration of astrocytes. The bold lines indicate the signaling cascade promoted by BDNF. The broken lines indicate a lack of signal transduction.

truncated T1 TrkB neurotrophin receptor. Biochem Biophys Res Commun 279:925-930.

Maekawa M, Ishizaki T, Boku S, Watanabe N, Fujita A, Iwamatsu A, Obinata T, Ohashi K, Mizuno K, Narumiya S (1999) Signaling from Rho to the actin cytoskeleton through protein kinases ROCK and LIM-kinase. Science 285:895-898.

Mehta D, Ahmmed GU, Paria BC, Holinstat M Voyno-Yasenetskaya T, Tiruppathi C, Minshall RD, Malik AB (2003) RhoA interaction with inositol 1,4,5-trisphosphate receptor and transient receptor potential channel-1 regulates $\mathrm{Ca}^{2+}$ entry. Role in signaling increased endothelial permeability. J Biol Chem 278:33492-33500.

Middlemas DS, Lindberg RA, Hunter T (1991) $\operatorname{trk} B$, a neural receptor protein-tyrosine kinase: evidence for a full-length and two truncated receptors. Mol Cell Biol 11:143-153.

Offenhäuser N, Muzio V, Biffo S (2002) BDNF binding to truncated trkB.T1 does not affect gene expression. NeuroReport 13:1189-1193.

Ohira K, Hayashi M (2003) Expression of TrkB subtypes in the adult monkey cerebellar cortex. J Chem Neuroanat 25:175-183.

Ohira K, Shimizu K, Hayashi M (1999) Change of expression of full-length and truncated TrkBs in the developing monkey central nervous system. Brain Res Dev Brain Res 112:21-29.

Ohira K, Shimizu K, Hayashi M (2001) TrkB dimerization during development of the prefrontal cortex of the macaque. J Neurosci Res 65:463-469.

Oliet SHR, Piet R, Poulain DA (2001) Control of glutamate clearance and synapse efficacy by glial coverage of neurons. Science 292:923-926.

Ploug M, Jensen AL, Barkholt V (1989) Determination of amino acid compositions and $\mathrm{NH}_{2}-$ terminal sequences of peptides electroblotted onto PVDF membranes from tricine-SDSPAGE: application to peptide mapping of human complement component C3. Anal Biochem 181:33-39.

Ren XD, Kiosses WB, Schwartz MA (1999) Reg-

Hirrlinger J, Hülsmann S, Kirchhoff F (2004) Astroglial processes show spontaneous motility at active synaptic terminals in situ. Eur J Neurosci 20:2235-2239.

Iino M, Goto K, Kakegawa W, Okado H, Sudo M, Ishiuchi S, Miwa A, Takayasu Y, Saito I, Tsuzuki K, Ozawa S (2001) Glia-synapse interaction through $\mathrm{Ca}^{2+}$-permeable AMPA receptors in Bergmann glia. Science 292:926-929.

Illenberger D, Schwald F, Pimmer D, Binder W, Maier G, Dietrich A, Gierschik P (1998) Stimulation of phospholipase C- $\beta_{2}$ by the Rho GTPases Cdc42Hs and Rac1. EMBO J 17:6241-6249.

Just I, Selzer J, von Eichel-Streiber C, Aktories K (1995) The low molecular mass GTP-binding protein Rho is affected by toxin A from Clostridium difficile. J Clin Invest 95:1026-1031.

Kaplan DR, Miller FD (2000) Neurotrophin signal transduction in the nervous system. Curr Opin Neurobiol 10:381-391.

Klein R, Conway D, Parada LF, Barbacid M (1990) The trkB tyrosine kinase gene codes for a second neurogenic receptor that lacks the catalytic kinase domain. Cell 61:647-656.

Knüsel B, Rabin SJ, Hefti F, Kaplan DR (1994) Regulated neurotrophin receptor responsiveness during neuronal migration and early differentiation. J Neurosci 14:1542-1554.

Kohara K, Kitamura A, Morishima M, Tsumoto T (2001) Activitydependent transfer of brain-derived neurotrophic factor to postsynaptic neurons. Science 291:2419-2423.

Kovalchuk Y, Holthoff K, Konnerth A (2004) Neurotrophin action on a rapid timescale. Curr Opin Neurobiol 14:558-563.

Kryl D, Barker PA (2000) TTIP is a novel protein that interacts with the ulation of the small GTP-binding protein Rho by cell adhesion and the cytoskeleton. EMBO J 18:578-585.

Ridley AJ (2001) Rho GTPases and cell migration. J Cell Sci 114:2713-2722.

Rose CR, Blum R, Pichler B, Lepier A, Kafitz KW, Konnerth A (2003) Truncated TrkB-T1 mediates neurotrophin-evoked calcium signalling in glia cells. Nature 426:74-78.

Sahara Y, Westbrook GL (1993) Modulation of calcium currents by a metabotropic glutamate receptor involves fast and slow kinetic components in cultured hippocampal neurons. J Neurosci 13:3041-3050.

Sasaki T, Takai Y (1998) The Rho small G protein family-Rho GDI system as a temporal and spatial determinant for cytoskeletal control. Biochem Biophys Res Commun 245:641-645.

Shelton DL, Sutherland J, Gripp J, Camerato T, Armanini MP, Phillips HS, Carroll K, Spencer SD, Levinson AD (1995) Human trks: molecular cloning, tissue distribution, and expression of extracellular domain immunoadhesins. J Neurosci 15:477-491.

Takai Y, Sasaki T, Matozaki T (2001) Small GTP-binding proteins. Physiol Rev 81:153-208.

Thoenen H (2000) Neurotrophins and activity-dependent plasticity. Prog Brain Res 128:183-191.

Yacoubian TA, Lo DC (2000) Truncated and full-length TrkB receptors regulate distinct modes of dendritic growth. Nat Neurosci 3:342-349.

Yamashita T, Tohyama M (2003) The p75 receptor acts as a displacement factor that releases Rho from Rho-GDI. Nat Neurosci 6:461-467.

Yamashita T, Tucker KL, Barde YA (1999) Neurotrophin binding to the p75 receptor modulates Rho activity and axonal outgrowth. Neuron 24:585-593. 